\title{
In-Depth 2D NMR Study of Lignin Modification During Pretreatment of Eucalyptus Wood with Laccase and Mediators
}

\author{
Alejandro Rico • Jorge Rencoret • José C. del Río • \\ Angel T. Martínez • Ana Gutiérrez
}

Published online: 14 August 2014

(C) Springer Science+Business Media New York 2014

\begin{abstract}
Eucalypt feedstock was pretreated with Myceliophthora thermophila laccase and methyl syringate, as mediator, in a multistage sequence consisting of successive enzymatic and alkaline peroxide stages, directly on the ground wood. Lignin modification was studied by two-dimensional (2D) nuclear magnetic resonance (NMR) of wood (at the gel state) after each stage of the sequence. Decrease of guaiacyl and syringyl lignin units (with preferential removal of the former) and aliphatic (mainly $\beta-O-4^{\prime}$-linked) side chains was observed along the sequence, without a substantial change in polysaccharide cross-signals along the sequence, was observed. However, the most noticeable modification was the formation of $\mathrm{C}_{\alpha}$-oxidized syringyl units in the enzymatic stages, which were partially removed in the alkaline extractions. Further insight was attained by 2D NMR of the cellulolytic-enzyme lignins, isolated from the pretreated samples, and the filtrates from the different stages. Additionally, a comparison of eucalypt delignification with the high redox potential laccase from Pycnoporus cinnabarinus in the presence of the synthetic mediator 1-hydroxybenzotriazole was carried out. Wood delignification already occurred at the first cycle of the pretreatment with P. cinnabarinus laccase and 1hydroxybenzotriazole, which directly correlated with increases in glucose $(\sim 10 \%)$ yields after enzymatic hydrolysis. In contrast, the first cycle of pretreatment with M. thermophila laccase and methyl syringate did not produce any delignification or saccharification improvement. However, at
\end{abstract}

Alejandro Rico and Jorge Rencoret contributed equally to this work.

A. Rico · J. Rencoret · J. C. del Río · A. Gutiérrez $(\triangle)$ Instituto de Recursos Naturales y Agrobiología de Sevilla, CSIC, Reina Mercedes 10, 41012 Seville, Spain

e-mail: anagu@irnase.csic.es

A. T. Martínez

Centro de Investigaciones Biológicas, CSIC,

Ramiro de Maeztu 9, 28040 Madrid, Spain the end of the sequence, similar delignification $(\sim 50 \%)$ of eucalypt feedstock and increases $(\sim 30 \%)$ in glucose yields were attained in both laccase-mediator pretreatments. Finally, the influence of lignin content and the ratio of its syringyl and guaiacyl units on recalcitrance of eucalypt feedstock to enzymatic saccharification is discussed.

Keywords Enzymatic delignification $\cdot$ Laccase mediator . Lignin $\cdot \mathrm{S} / \mathrm{G}$ ratio $\cdot 2 \mathrm{D}$ NMR $\cdot$ Bioethanol

\section{Introduction}

Bioconversion of lignocellulosic biomass is an attractive route for the sustainable production of liquid transportation fuels. However, the conversion of lignocellulosic biomass, constituted mainly by cellulose, hemicelluloses, and lignin linked into a complex matrix, is challenged by its recalcitrant structure. Biomass recalcitrance toward saccharification correlates with the content and composition of lignin [1-3]. Lignin is a three-dimensional polymer constituted by phenylpropanoid subunits linked together by a variety of ether and carboncarbon bonds. Lignin is intimately interlaced with hemicelluloses in the plant cell wall forming a matrix to cover the crystalline cellulose microfibrils. Its aromatic nature and complex structure makes lignin degradation very difficult. Lignin has been shown to have a detrimental effect on the hydrolysis of biomass because it physically hinders the accessibility of cellulases and also binds cellulases leading to their inactivation [4-7].

Biofuel production from lignocellulosic material requires deconstruction of the cell wall into individual constituents and hydrolysis of the carbohydrates into monomeric sugars followed by fermentation to ethanol. Biomass pretreatment is intended to increase enzyme accessible cellulosic surface area that can be accomplished through the removal of lignin, 
and biotechnology can contribute to plant biomass deconstruction by providing biocatalysts being able to degrade or modify lignin [8]. Among these, laccases are promising enzymes with great biotechnological potential. Laccases (phenoloxidases, EC 1.10.3.2) are multicopper oxidases that oxidize substituted phenols using molecular oxygen as the final electron acceptor. The direct action of laccases on lignin is, in principle, restricted to phenolic units that only represent a small percentage of the total polymer, a fact that limits their biotechnological application. However, the discovery that some synthetic compounds can act as electron carriers between the enzyme and the final substrate [9], 1hydroxybenzotriazole (HBT) being among the most efficient ones [10], has expanded the utility of laccases. A number of studies have confirmed the potential of laccase-mediator systems for paper pulp delignification [11, 12], pitch control [13], polymer modification [14], and other applications in the forest industry [15]. The ability of high redox potential laccases (e.g., from Trametes species) to remove lignin (when applied in combination with synthetic mediators, based on nitrogen heterocycles) from whole [16] or pretreated [17, 18] lignocellulosic biomass, making cellulose accessible to hydrolysis, was reported.

Recently, a low redox potential laccase from the ascomycete Myceliophthora thermophila in combination with the natural mediator methyl syringate (MeS) was tested for the removal of lignin from Eucalyptus globulus wood feedstock [19]. After a multistage sequence, up to $50 \%$ lignin removal was attained that was directly correlated with increases (approximately $40 \%$ ) in glucose and xylose yields after enzymatic hydrolysis. In the present work, a thorough two-dimensional nuclear magnetic resonance (2D NMR) study of lignin modification after each step of the Eucalyptus wood pretreatment multistage sequence, consisting of successive M. thermophila laccase and MeS and alkaline peroxide stages, has been performed. Both the pretreated eucalypt wood and the corresponding filtrates obtained after each stage of pretreatment have been analyzed by 2D NMR, together with the cellulolytic enzyme lignin (CEL) isolated from the pretreated wood. Additionally, a comparison of eucalypt wood delignification with the high redox potential laccase from Pycnoporus cinnabarinus in the presence of the synthetic mediator HBT and its effect on saccharification yield was also carried out along the several stages of the sequence. The aim of the present study is not to develop a cost-effective pretreatment but to provide detailed chemical information about the eucalypt lignin modification by a commercial laccase and a phenolic mediator (as well as by the subsequent alkaline peroxide extraction) in the course of a model multistage sequence, and the effect of lignin removal on enzymatic hydrolysis, that will help to develop economically viable pretreatments.

\section{Material and Methods}

\section{Wood, Enzyme, and Mediator}

Eucalypt (E. globulus) wood chips from ENCE (Pontevedra, Spain), were air-dried and grounded in an IKA MF10 cutting mill to pass through a 100-mesh screen and then finely milled using a Retsch PM100 planetary mill at 400 rev min$^{-1}$ (with $5 \mathrm{~min}$ breaks after every $5 \mathrm{~min}$ of milling) using a $500-\mathrm{ml}$ agate jar and agate ball bearings $(20 \times 20 \mathrm{~mm})$. The total ball milling time for the samples was $5 \mathrm{~h}$.

A commercial (recombinant) fungal laccase from the ascomycete $M$. thermophila, provided by Novozymes (Bagsvaerd, Denmark), was used in this study. Its activity was measured as initial velocity during oxidation of $5 \mathrm{mM}$ ABTS from Roche to its cation radical $\left(\varepsilon_{436} 29,300 \mathrm{M}^{-1} \mathrm{~cm}^{-1}\right)$ in $0.1 \mathrm{M}$ sodium acetate $(\mathrm{pH} 5)$ at $24{ }^{\circ} \mathrm{C}$. The laccase activity of the enzyme preparation was $945 \mathrm{U} / \mathrm{ml}$. One activity unit (U) was defined as the amount of enzyme transforming $1 \mu \mathrm{mol}$ of ABTS per min. A fungal laccase preparation $(45 \mathrm{U} / \mathrm{ml})$ obtained from a laccase-hyperproducing strain of the basidiomycete $P$. cinnabarinus that was provided by Beldem (Andenne, Belgium) was also used for comparative studies.

MeS from Alfa Aesar (Karlsruhe, Germany) and HBT from Sigma-Aldrich (Steinheim, Germany) were used as mediators.

\section{Laccase-Mediator Treatments}

The eucalypt samples were treated with the $M$. thermophila laccase in the presence (and absence) of MeS, as mediator. Laccase doses of $50 \mathrm{U} \mathrm{g}^{-1}$ were assayed, together with $3 \%$ $\mathrm{MeS}$, both referred to wood dry weight. The treatments were carried out in 200-ml pressurized bioreactors (Labomat, Mathis) placed in a thermostatic shaker at $170 \mathrm{rev} \mathrm{\textrm {min } ^ { - 1 }}$ and $50{ }^{\circ} \mathrm{C}$, using $10 \mathrm{~g}$ (dry weight) samples at $6 \%$ consistency $(w / w)$ in $50 \mathrm{mM}$ sodium dihydrogen phosphate ( $\mathrm{pH}$ 6.5) under $\mathrm{O}_{2}$ atmosphere (2 bars) for $24 \mathrm{~h}$. After the treatment, the samples were filtered through a Büchner funnel and washed with $1 \mathrm{~L}$ of water. In a subsequent stage, samples at $6 \%$ consistency $(w / w)$ were submitted to a peroxide-reinforced alkaline extraction using $1 \%(w / w)$ $\mathrm{NaOH}$ and $3 \%(w / w) \mathrm{H}_{2} \mathrm{O}_{2}$ (also with respect to sample dry weight) at $80{ }^{\circ} \mathrm{C}$ for 90 min followed by water washing [20]. Cycles of four successive enzyme-extraction treatments were applied. Treatments with laccase $\left(50 \mathrm{U} \mathrm{g} \mathrm{g}^{-1}\right)$ alone (without mediator) and controls without laccase and mediator were also performed (followed in both cases by the corresponding alkaline extractions). Each filtrate from the pretreatment stages (including enzymatic treatments and alkaline peroxide extractions) were recovered and freezedried. Eucalypt treatments with $P$. cinnabarinus laccase were 
performed as described above for $M$. thermophila ones, but using $50 \mathrm{mM}$ sodium tartrate (pH 4) as a buffer and HBT as mediator. Klason lignin content was estimated according to T222 om-88 [21].

\section{Saccharification of Treated Wood}

The laccase-pretreated samples were hydrolyzed with a cocktail containing commercial enzymes (from Novozymes, Bagsvaerd) with cellulase (Celluclast $1.5 \mathrm{~L} ; 2 \mathrm{FPU} \cdot \mathrm{g}^{-1}$ ) and $\beta$-glucosidase (Novozym 188; 100 nkat $^{-1}$ ) activities, at $1 \%$ consistency in $3 \mathrm{ml}$ of $100 \mathrm{mM}$ sodium citrate (pH 5) for $72 \mathrm{~h}$ at $45^{\circ} \mathrm{C}$, in a thermostatic shaker at $170 \mathrm{rev} \mathrm{m^{-1 }}$ (in triplicate experiments).

The different monosaccharides released were determined as alditol acetates [22] by GC. An Agilent 6890 N Network GC system equipped with a split-splitless injector and a flame ionization detector was used. The injector and detector temperatures were set at 225 and $250{ }^{\circ} \mathrm{C}$, respectively. Samples were injected in the split mode (split ratio 10:1). Helium was used as the carrier gas. The capillary column used was a DB-225 (30 $\mathrm{m} \times 0.25 \mathrm{~mm}$ i.d., $0.15 \mu \mathrm{m}$ film thickness; Agilent $\mathrm{J} \& \mathrm{~W})$. The oven was temperature-programmed from $220^{\circ} \mathrm{C}$ (held for $5 \mathrm{~min}$ ) to $230{ }^{\circ} \mathrm{C}$ (held for $5 \mathrm{~min}$ ) at $2{ }^{\circ} \mathrm{C} \mathrm{min}^{-1}$. Peaks were quantified by area and glucose, xylose, and arabinose were used as standards to elaborate calibration curves. The data from the three replicates were averaged.

\section{Isolation of CEL}

The air-dried eucalypt samples were extracted three times with water and subsequently three times with $80 \%$ ethanol by sonicating in an ultrasonic bath for 30 min each time. CEL preparations were isolated by enzymatically saccharifying polysaccharides as described by Chang et al. (1975). Cellulysin cellulase (Calbiochem), a crude cellulase preparation from Trichoderma viride also containing hemicellulase activities, was used. Its activity was $\geq 10,000 \mathrm{FPU} \mathrm{g}^{-1}$ of dry weight. The ball-milled material $(200 \mathrm{mg}$ ) was suspended in $30 \mathrm{ml}$ of $20 \mathrm{mM}$ sodium acetate ( $\mathrm{pH} 5.0$ ) in a 50-ml centrifuge tube, $7.5 \mathrm{mg}$ of cellulysin was added, and the reaction slurry was incubated at $30^{\circ} \mathrm{C}$ for $48 \mathrm{~h}$. The solids were pelleted by centrifugation $\left(8,000 \mathrm{rpm}, 4^{\circ} \mathrm{C}, 20 \mathrm{~min}\right)$, and the process was repeated with fresh buffer and enzyme, three times. Finally, the residue (CEL) was washed with distillated water, recovered by centrifugation and freeze dried.

\section{D NMR Spectroscopy}

For gel-state NMR experiments, $\sim 100 \mathrm{mg}$ of finely divided (ball-milled) wood samples (and filtrate samples) after the several steps of the whole multistage sequence were directly transferred into 5-mm NMR tubes, and swelled in $1 \mathrm{ml}$ of
DMSO- $d_{6}$, forming a gel inside the NMR tube $[23,24]$. For a more in-depth structural characterization of the lignins, around $30 \mathrm{mg}$ of CEL preparations were dissolved in $0.75 \mathrm{ml}$ of DMSO- $d_{6}$.

HSQC 2D-NMR spectra were acquired at $25{ }^{\circ} \mathrm{C}$ on a Bruker AVANCE III $500 \mathrm{MHz}$ spectrometer fitted with a cryogenically cooled $5 \mathrm{~mm}$ TCI gradient probe with inverse geometry (proton coils closest to the sample). The $2 \mathrm{D}^{13} \mathrm{C}-{ }^{1} \mathrm{H}$ correlation spectra were carried out using an adiabatic HSQC pulse program (Bruker standard pulse sequence "hsqcetgpsisp2.2") and the following parameters: spectra were acquired from 10 to $0 \mathrm{ppm}(5,000 \mathrm{~Hz})$ in F2 $\left({ }^{1} \mathrm{H}\right)$ using 1,000 data points for an acquisition time (AQ) of $100 \mathrm{~ms}$, an interscan delay (D1) of $1 \mathrm{~s}$, and from 200 to $0 \mathrm{ppm}(25,168)$ in F1 $\left({ }^{13} \mathrm{C}\right)$ using 256 increments of 32 scans, for a total acquisition time of $2 \mathrm{~h} 34 \mathrm{~min}$. The ${ }^{1} J_{\mathrm{CH}}$ used was $145 \mathrm{~Hz}$. Processing used typical matched Gaussian apodization in ${ }^{1} \mathrm{H}$ and a squared cosine bell in ${ }^{13} \mathrm{C}$. The central solvent peak was used as an internal reference $\left(\delta_{\mathrm{C}} / \delta_{\mathrm{H}} 39.5 / 2.49\right)$. The ${ }^{13} \mathrm{C}-{ }^{1} \mathrm{H}$ correlation signals from the aromatic region of the spectrum were used to estimate the lignin composition in terms of $\mathrm{G}, \mathrm{S}$, and oxidized $\mathrm{S}\left(\mathrm{S}^{\prime}\right)$ units, and those of the aliphaticoxygenated region were used to estimate the inter-unit linkage and end unit abundances. The $\mathrm{S}$ lignin content in the laccasemediator treated sample was corrected for the contribution of MeS to the 106/7.3 ppm signal, which was estimated from the integral of its characteristic signal at 52/3.8 ppm.

\section{Results}

The purpose of the present work is to analyze in detail the chemical modifications produced in eucalypt feedstock and its recalcitrant lignin moiety after each step of the multistage sequence consisting of four successive enzymatic treatments with the commercial M. thermophila laccase and mediator, followed by alkaline peroxide extraction stages. Additionally, the efficiency of this low redox potential laccase and the MeS mediator in lignin removal and improvement in saccharification yield after enzymatic hydrolysis was compared with that of a high redox potential laccase and a synthetic mediator along the multistage sequence.

Samples of the whole lignocellulosic material (and also their isolated CEL preparations) including controls, samples pretreated with laccases alone (from M. thermophila and $P$. cinnabarinus), and samples pretreated with the two laccases and mediators (MeS and HBT, respectively) and filtrates recovered after each stage of the sequence were thoroughly studied by 2D NMR. Semiquantitative data on lignin modification during the multistage sequence were obtained by volume integrals of aromatic and aliphatic lignin signals (providing information on the amount of lignin $\mathrm{S}$ and $\mathrm{G}$ units, and 
side-chain inter-unit linkages, respectively) in the above 2D NMR spectra, which were obtained using an adiabatic pulse program that largely corrects previous intensity problems due to differences in ${ }^{1} J_{\mathrm{CH}}$ values and magnetization losses (offset effects) in different regions of the HSQC spectrum.

\section{Lignin Modification Along the M. thermophila Laccase-MeS Pretreatment}

\section{D NMR Analyses of the Whole Pretreated Samples}

The modification of lignin structure during the laccasemediator treatment of eucalypt wood was studied after each of the eight stages, including four enzymatic treatments under oxygen (stages 1, 3, 5, and 7), each followed by an alkaline peroxide extraction (stages 2, 4, 6, and 8). With this purpose, all the pretreated eucalypt samples (and the corresponding controls) were analyzed by 2D NMR at the gel state (Figs. 1, 2, and 3; Table 1). The initial wood sample (without any treatment) was also analyzed. The main lignin structures identified are shown in Fig. 4, and the different lignin signals assigned on the spectra are listed in Table 2. The aliphaticoxygenated region of the HSQC spectrum of the initial eucalypt wood (Fig. 1a, top right) shows signals of lignin and carbohydrates, the latter mainly corresponding to xylan (X) and acetylated xylan $\left(\mathrm{X}^{\prime}\right)$ units, since crystalline cellulose is nearly "silent" in lignocellulose gel spectra under solution NMR conditions. In this region, signals of side-chains in $\beta$ $O-4^{\prime}$ alkyl-aryl ether lignin substructures (A), including $\mathrm{C}_{\gamma^{-}}$ $\mathrm{H}_{\gamma}, \mathrm{C}_{\beta}-\mathrm{H}_{\beta}$, and $\mathrm{C}_{\alpha}-\mathrm{H}_{\alpha}$ correlations $\left(\mathrm{A}_{\gamma}, \mathrm{A}_{\beta}\right.$, and $\mathrm{A}_{\alpha}$, respectively) were observed. The $\mathrm{A}_{\gamma}$ signal overlaps with related signals in lignin and other lignocellulose constituents. The $\mathrm{C}_{\beta}-\mathrm{H}_{\beta}$ correlations gave two different signals corresponding to $\beta-O-4^{\prime}$ substructures where the second unit is an $\mathrm{S}$ unit or a $G$ unit $\left(A_{\beta(S)}\right.$ and $\left.A_{\beta(G)}\right)$, the latter with lower intensity, in agreement with lignin composition described below. Other less prominent signals for resinol $\left(\beta-\beta^{\prime}\right)$ substructures $(C)$ were also observed in the spectrum, with their $\mathrm{C}_{\alpha}-\mathrm{H}_{\alpha}, \mathrm{C}_{\beta}-$ $\mathrm{H}_{\beta}$ and the double $\mathrm{C}_{\gamma}-\mathrm{H}_{\gamma}$ correlations $\left(\mathrm{C}_{\alpha}, \mathrm{C}_{\beta}\right.$, and $\left.\mathrm{C}_{\gamma}\right)$. The main signals in the aromatic region of the HSQC spectrum (Fig. 1a, bottom left) correspond to the benzenic rings of the $\mathrm{S}$ and $\mathrm{G}$ lignin units. The S-lignin units showed a prominent signal for the $\mathrm{C}_{2,6}-\mathrm{H}_{2,6}$ correlation $\left(\mathrm{S}_{2,6}\right)$, while the G-lignin units showed different correlations for $\mathrm{C}_{2}-\mathrm{H}_{2}\left(\mathrm{G}_{2}\right), \mathrm{C}_{5}-\mathrm{H}_{5}\left(\mathrm{G}_{5}\right)$, and $\mathrm{C}_{6}-\mathrm{H}_{6}\left(\mathrm{G}_{6}\right)$. Signals corresponding to $\mathrm{C}_{2,6}-\mathrm{H}_{2,6}$ correlations in $\mathrm{C}_{\alpha}$-oxidized $\mathrm{S}$-lignin units $\left(\mathrm{S}_{2,6}^{\prime}\right)$ were also observed although in low amount. From the integrals of the above signals, an syringyl-to-guaiacyl (S/G) ratio around 3.5 and a large predominance of $\beta-O-4^{\prime}$ ether linkages, together with some resinols, were estimated for lignin in E. globulus wood (Table 1).

Figure $1 \mathrm{~b}-\mathrm{i}$ shows the HSQC spectra of the eucalypt controls (treated under the same conditions of the laccase- mediator treatments but without laccase and mediator). In the aliphatic oxygenated region of the spectra, it can be observed that during the control pretreatment acetylated xylan units $\left(X^{\prime}\right)$ decrease considerably after the first alkaline extraction (stage 2, Fig. 1c) and completely disappeared with the second alkaline extraction (stage 4 ) while the non-acetylated ones $(\mathrm{X})$ remain. The $\beta-O-4^{\prime}$ alkyl-aryl ethers and resinol substructures decreased slightly along the sequence and after the last stage the lignin in control were mainly constituted by the former substructures although the latter were still present (Table 1). The most significant effect of the control pretreatment conditions was the increase in the $\mathrm{S} / \mathrm{G}$ ratio along the sequence that particularly took place in the oxygen stages and was especially evident in the stage 7.

The 2D NMR analyses of gels of the eucalypt samples treated with $M$. thermophila laccase alone (followed by alkaline treatments) (Fig. 2, Table 1) revealed a decrease in the $\beta$ $O-4^{\prime}$ alkyl-aryl ethers and resinol substructures along the sequence showing the sharpest decrease in the second enzymatic treatment (stage 3). Concerning lignin units, an increase in the $\mathrm{S} / \mathrm{G}$ ratio was observed along the sequence that was especially significant along the third and fourth cycles of treatment. One effect of the enzymatic treatment with M. thermophila laccase (not observed along the control sequence) was the increase in $\mathrm{C}_{\alpha}$-oxidized lignin units $\left(\mathrm{S}^{\prime}\right)$ produced in the enzymatic stages 3,5 , and 7 .

However, the most noticeable changes were observed in the pretreatment of eucalypt wood with $M$. thermophila laccase in the presence of MeS (Fig. 3, Table 1). This included the complete absence of $\mathrm{G}$ units and resinol substructures, together with a high decrease in $\beta-O-4^{\prime}$ alkyl-aryl ethers, after two cycles of laccase-mediator treatment and alkaline extraction (stage 5), although the most remarkable decreases in these units and substructures were already observed after the first cycle of treatment (stage 3 ) at the same time that the signals corresponding to $\beta-O-4$ ' substructures where the second unit is a $G$ unit $\left(\mathrm{A}_{\beta(\mathrm{G})}\right)$ dissapeared (Fig. 3d). Likewise, the most remarkable increase in $\mathrm{C}_{\alpha}$-oxidized lignin units $\left(\mathrm{S}^{\prime}\right)$ was also observed in stage 3 . Interestingly, the amount of these oxidized lignin units decreased in all cases with the alkaline extraction (stages 2, 4, 6, and 8).

2D NMR Analyses of the Lignins Isolated from the Pretreated Samples

To gain more insight into the modification of lignin structure along the multistage laccase-mediator treatment sequence, CEL was isolated from the pretreated eucalypt samples, and analyzed by 2D NMR (Fig. 5). The lignin structures identified, some of them not detected in the wood spectra, are shown in Fig. 4, and the corresponding signal assignments are listed in Table 2, together with those found in the whole wood spectra. Table 3 shows the lignin composition and percentages of inter- 

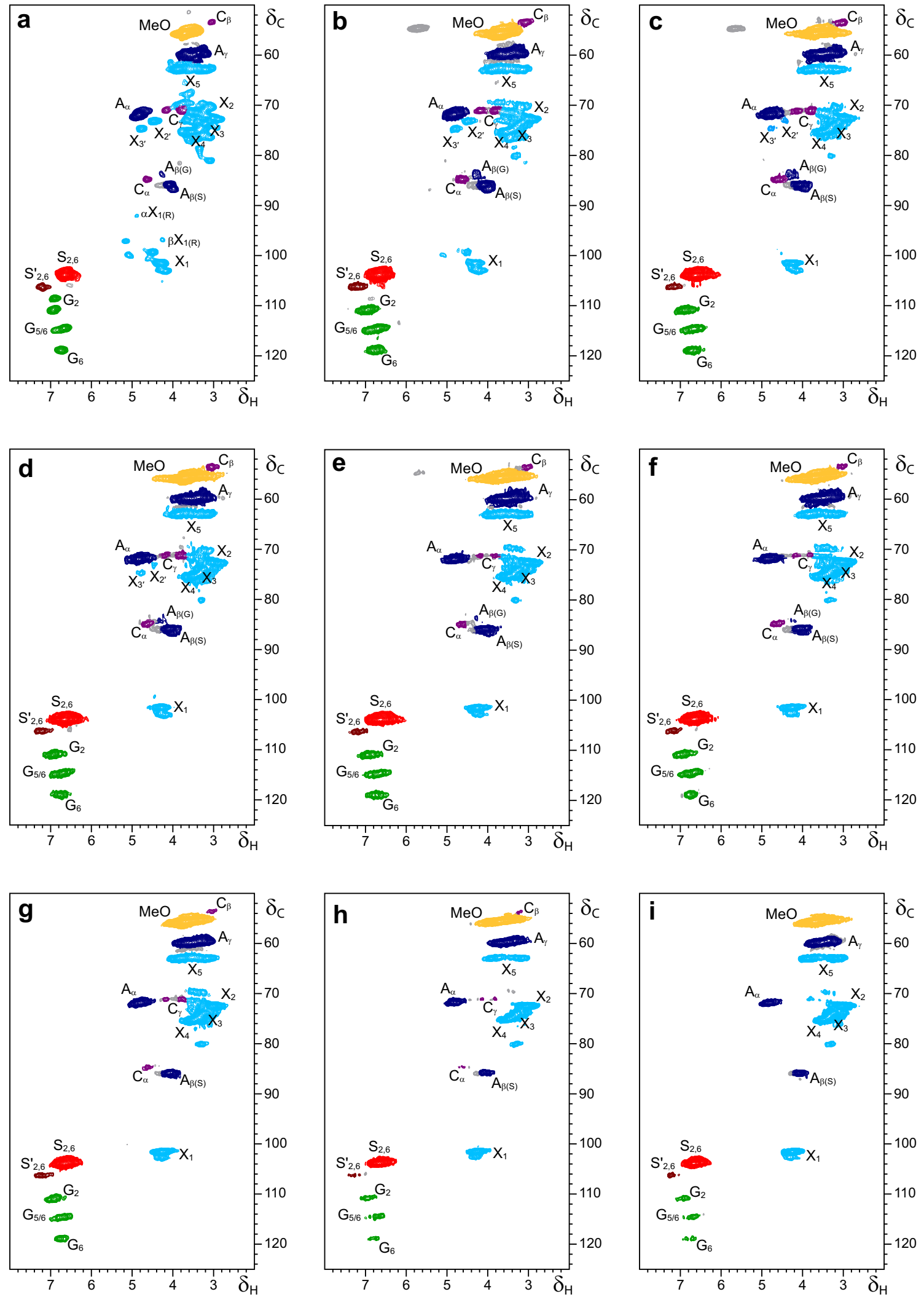

Fig. 1 HSQC NMR spectra of whole eucalypt wood (control samples without enzyme) swollen in DMSO- $d_{6}$, from a multistage enzymatic sequence, including four treatments with $M$. thermophila laccase-MeS and 4 alkaline peroxide extractions: a initial eucalypt sample; $\mathbf{b}, \mathbf{d}, \mathbf{f}$, and h controls of first, second, third, and fourth enzymatic pretreatment

(stages 1, 3, 5, and 7, respectively); $\mathbf{c}, \mathbf{e}, \mathbf{g}$, and $\mathbf{i}$ controls of first, second, third, and fourth alkaline peroxide extractions (stages 2, 4, 6, and 8, respectively). See Table 1 for quantification of the lignin structures identified, Table 2 for signal assignment, and Fig. 4 for the main lignin structures identified 

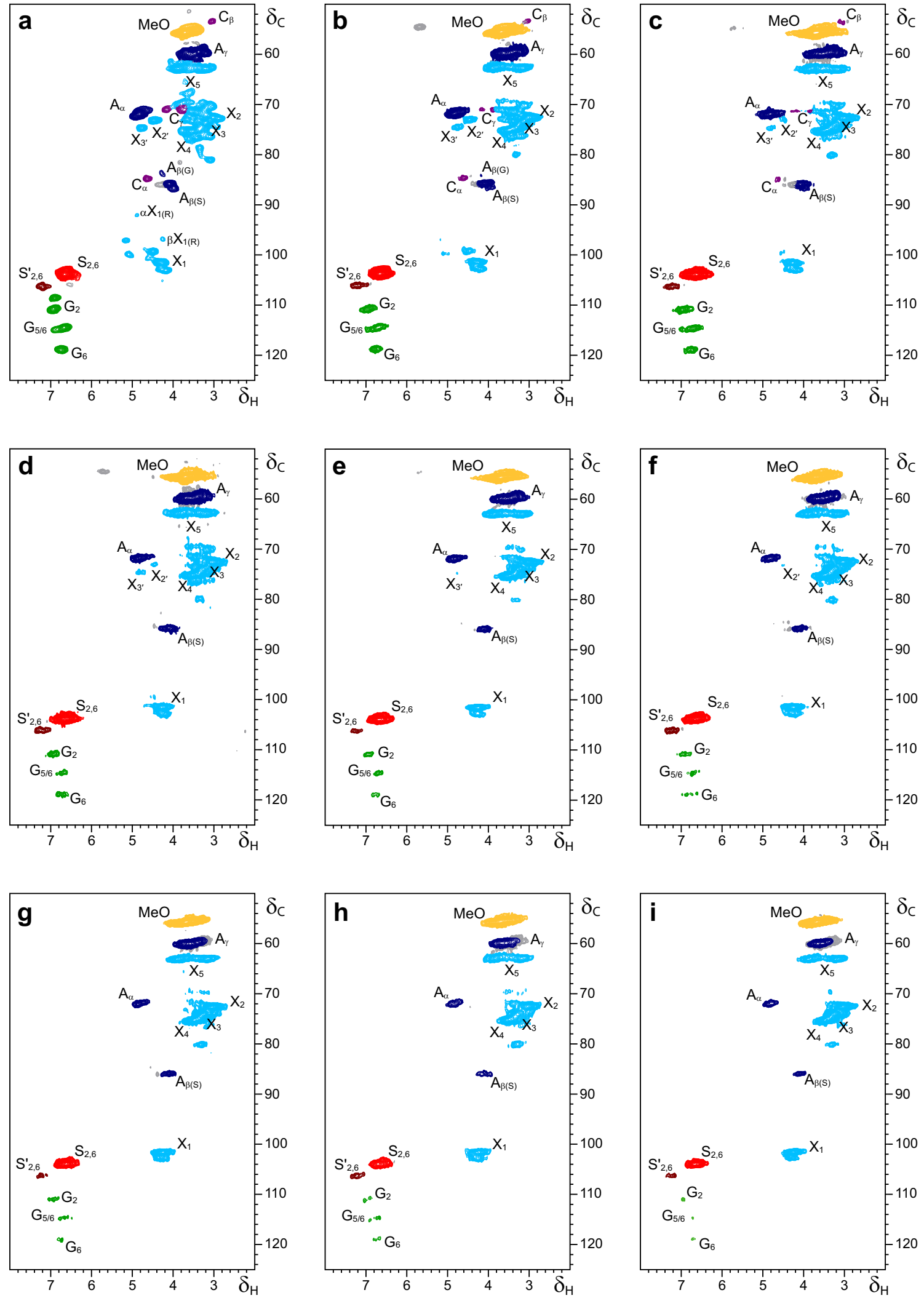

Fig. 2 HSQC NMR spectra of whole eucalypt wood (samples treated with $M$. thermophila laccase alone) swollen in DMSO- $d_{6}$, from a multistage enzymatic sequence, including four treatments with $M$. thermophila laccase-MeS and four alkaline peroxide extractions: a initial eucalypt sample; b, d, f, and $\mathbf{h}$ samples from first, second, third, and fourth

enzymatic pretreatment with laccase alone (stages 1, 3, 5, and 7, respectively); c, e, g, and i samples from first, second, third, and fourth alkaline peroxide extractions (stages 2, 4, 6, and 8, respectively). See Table 1 for quantification of the lignin structures identified, Table 2 for signal assignment, and Fig. 4 for the main lignin structures identified 

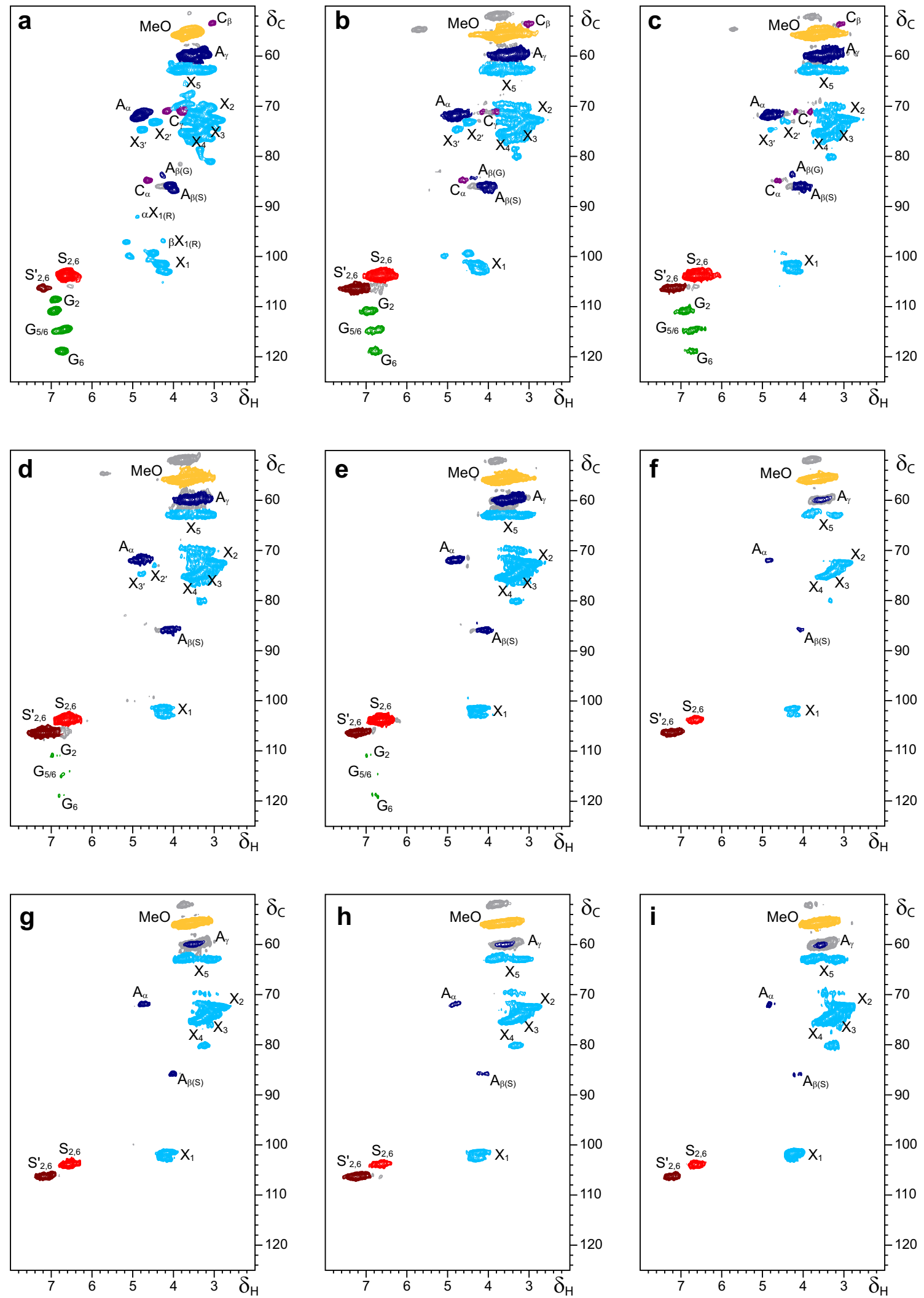

Fig. 3 HSQC NMR spectra of whole eucalypt (samples treated with M. thermophila laccase and MeS) swollen in DMSO- $d_{6}$, from a multistage enzymatic sequence, including four treatments with $M$. thermophila laccase-MeS and four alkaline peroxide extractions: a initial eucalypt sample; b, d, f, and $\mathbf{h}$ samples from first, second, third, and fourth

enzymatic pretreatment with laccase and mediator (stages 1, 3, 5, and 7, respectively); c, e, g, and i samples from first, second, third, and fourth alkaline peroxide extractions (stages 2, 4, 6, and 8, respectively). See Table 1 for quantification of the lignin structures identified, Table 2 for signal assignment, and Fig. 4 for the main lignin structures identified 
Table 1 Lignin units $\left(\mathrm{S}, \mathrm{G}\right.$, and $\mathrm{S}^{\prime}$ molar percentages) and inter-unit linkages (side-chains per 100 phenylpropanoid units) from the HSQC spectra of eucalypt samples from a multistage enzymatic sequence, including 4 treatments with $M$. thermophila laccase-MeS (stages 1, 3, 5 and 7) and 4 alkaline peroxide extractions (stages 2, 4, 6 and 8), compared with a control without enzyme, a treatment with laccase alone (including similar stages) and initial eucalypt wood

\begin{tabular}{|c|c|c|c|c|c|c|c|c|c|}
\hline & \multirow[t]{2}{*}{ Initial wood } & \multicolumn{8}{|c|}{ Whole treated wood (different stages) } \\
\hline & & 1 & 2 & 3 & 4 & 5 & 6 & 7 & 8 \\
\hline \multicolumn{10}{|l|}{ Control } \\
\hline \multicolumn{10}{|l|}{ Lignin units } \\
\hline Syringyl (S) (\% total) & 78 & 74 & 75 & 76 & 75 & 76 & 76 & 79 & 79 \\
\hline Guaiacyl $(\mathrm{G})(\%$ total $)$ & 22 & 26 & 25 & 24 & 25 & 24 & 24 & 21 & 21 \\
\hline $\mathrm{C} \alpha$-oxidized $\mathrm{S}$ units $\left(\mathrm{S}^{\prime}\right)(\% \mathrm{~S})$ & 12 & 10 & 8 & 9 & 9 & 7 & 12 & 10 & 10 \\
\hline $\mathrm{S} / \mathrm{G}$ ratio & 3.5 & 2.8 & 2.9 & 3.1 & 2.9 & 3.2 & 3.3 & 3.8 & 3.7 \\
\hline \multicolumn{10}{|l|}{ Lignin inter-unit linkages $(\% \mathrm{~S}+\mathrm{G})$} \\
\hline$\beta-O-4^{\prime}$ alkyl-aryl ethers (A) & 64 & 58 & 58 & 56 & 51 & 54 & 53 & 45 & 50 \\
\hline Phenylcoumarans (B) & 0 & 1 & 0 & 0 & 0 & 0 & 0 & 0 & 0 \\
\hline Resinols (C) & 10 & 10 & 8 & 9 & 5 & 6 & 7 & 5 & 5 \\
\hline Spirodienones (D) & 0 & 1 & 1 & 0 & 0 & 1 & 0 & 0 & 0 \\
\hline Total & 74 & 71 & 67 & 65 & 57 & 60 & 60 & 50 & 54 \\
\hline \multicolumn{10}{|l|}{ M. thermophila laccase } \\
\hline \multicolumn{10}{|l|}{ Lignin units } \\
\hline Syringyl (S) (\% total) & & 78 & 78 & 80 & 78 & 83 & 84 & 84 & 86 \\
\hline Guaiacyl $(G)(\%$ total $)$ & & 22 & 22 & 20 & 22 & 17 & 16 & 16 & 14 \\
\hline $\mathrm{C} \alpha$-oxidized $\mathrm{S}$ units $\left(\mathrm{S}^{\prime}\right)(\% \mathrm{~S})$ & & 13 & 11 & 14 & 12 & 19 & 13 & 18 & 16 \\
\hline $\mathrm{S} / \mathrm{G}$ ratio & & 3.5 & 3.5 & 4.0 & 3.5 & 4.7 & 5.3 & 5.3 & 6.2 \\
\hline \multicolumn{10}{|l|}{ Lignin inter-unit linkages $(\% \mathrm{~S}+\mathrm{G})$} \\
\hline$\beta-O-4^{\prime}$ alkyl-aryl ethers (A) & & 58 & 54 & 46 & 48 & 43 & 45 & 46 & 43 \\
\hline Phenylcoumarans (B) & & 0 & 0 & 0 & 0 & 0 & 0 & 0 & 0 \\
\hline Resinols (C) & & 9 & 5 & 2 & 5 & 3 & 2 & 0 & 0 \\
\hline Spirodienones (D) & & 0 & 0 & 0 & 0 & 0 & 0 & 0 & 0 \\
\hline Total & & 68 & 59 & 48 & 53 & 46 & 47 & 46 & 43 \\
\hline \multicolumn{10}{|l|}{ M. thermophila laccase-MeS } \\
\hline \multicolumn{10}{|l|}{ Lignin units } \\
\hline Syringyl (S) (\% total) & & 86 & 84 & 96 & 94 & 100 & 100 & 100 & 100 \\
\hline Guaiacyl $(\mathrm{G})(\%$ total $)$ & & 14 & 16 & 4 & 6 & 0 & 0 & 0 & 0 \\
\hline $\mathrm{C} \alpha$-oxidized $\mathrm{S}$ units $\left(\mathrm{S}^{\prime}\right)(\% \mathrm{~S})$ & & 44 & 26 & 64 & 37 & 65 & 46 & 67 & 47 \\
\hline $\mathrm{S} / \mathrm{G}$ ratio & & 6.2 & 5.4 & 25.2 & 15.2 & - & - & - & - \\
\hline \multicolumn{10}{|l|}{ Lignin inter-unit linkages $(\% \mathrm{~S}+\mathrm{G})$} \\
\hline$\beta-O-4^{\prime}$ alkyl-aryl ethers (A) & & 40 & 46 & 24 & 33 & 19 & 31 & 32 & 24 \\
\hline Phenylcoumarans (B) & & 0 & 0 & 0 & 0 & 0 & 0 & 0 & 0 \\
\hline Resinols (C) & & 6 & 8 & 1 & 1 & 0 & 0 & 0 & 0 \\
\hline Spirodienones (D) & & 0 & 0 & 0 & 0 & 0 & 0 & 0 & 0 \\
\hline Total & & 46 & 54 & 25 & 34 & 19 & 31 & 32 & 24 \\
\hline
\end{tabular}

unit linkages in the CEL samples at the beginning (cycle 1) and at the end (cycle 4) of pretreatment (stages 2 and 8, respectively) estimated from the signal volume integrals of 2D NMR spectra as described for the wood spectra.

The HSQC spectra of CEL preparations from control samples after one and four cycles of treatment (Fig. 5a, b) showed the same side-chain signals observed in the spectra of the corresponding whole eucalypt control samples (stages 2 and 8) (Fig. 1c, i), corresponding to $\beta-O-4^{\prime}$ alkyl-aryl ether (A) and resinol $(\mathrm{C})$ correlations, although better resolved and with higher intensity, and several new signals that could not be observed in the wood spectra. The latter included: (D) spirodienone $\left(\beta-1^{\prime} / \alpha-\mathrm{O}-\alpha^{\prime}\right)$ substructures with their $\mathrm{C}_{\alpha}-\mathrm{H}_{\alpha}$, $\mathrm{C}_{\alpha^{\prime}}-\mathrm{H}_{\alpha^{\prime}}, \mathrm{C}_{\beta}-\mathrm{H}_{\beta}$, and $\mathrm{C}_{\beta},-\mathrm{H}_{\beta^{\prime}}$ correlations $\left(\mathrm{D}_{\alpha}, \mathrm{D}_{\alpha^{\prime}}, \mathrm{D}_{\beta}, \mathrm{D}_{\beta^{\prime}}\right)$; (B) small signals corresponding to phenylcoumaran $\left(\beta-5^{\prime}\right)$ substructures with their $\mathrm{C}_{\alpha}-\mathrm{H}_{\alpha}, \mathrm{C}_{\beta}-\mathrm{H}_{\beta}$, and $\mathrm{C}_{\gamma}-\mathrm{H}_{\gamma}$ correlations ( $\mathrm{B}_{\alpha}, \mathrm{B}_{\beta}$, and $\mathrm{B}_{\gamma}$; the two latter correlations overlapping with other signals); (I) a signal of cinnamyl alcohol endgroups with its $\mathrm{C}_{\gamma}-\mathrm{H}_{\gamma}$ correlation; and $\left(\mathrm{A}_{\mathrm{ox} \beta}\right)$ signals of $\mathrm{C}_{\beta}-\mathrm{H}_{\beta}$ correlations in $\mathrm{C}_{\alpha}$-oxidized $\beta-O-4^{\prime}$ alkyl-aryl ether substructures (Fig. 4). The main signals in the aromatic region of the spectrum of the initial eucalypt CEL sample 
Fig. 4 Main lignin structures identified in the eucalypt samples analyzed by HSQC NMR

(Figs. 1, 2, 3 5, 6, and 7): $A \beta-O-4^{\prime}$ lignin substructures (including a second $\mathrm{S}$ or $\mathrm{G}$ unit); Aox $\mathrm{C}_{\alpha^{-}}$ oxidized $\beta-O-4^{\prime}$ lignin

substructures (including a second $\mathrm{S}$ or $\mathrm{G}$ unit); $B$ phenylcoumarans; $C$ resinols; $D$ spirodienones; $I$ cinnamyl alcohol end-groups, $G$ guaiacyl units, $S$ syringyl units, and $S^{\prime} \mathrm{C}_{\alpha}$-oxidized $\mathrm{S}$ units (R can be a hydroxyl in carboxylic acids or a lignin side-chain in ketones)<smiles>COc1cc(C(O)C(CO)Oc2c(C)cc(I)cc2OC)cc(C)c1OC</smiles>

A<smiles>COc1cc(C(=O)[C@H](Oc2c(C)cc(I)cc2OC)C(C)O)cc(C)c1OC</smiles>

$A_{\text {ox }}$<smiles>[3H]C(O)[C@@H]1c2cc(C)cc(OC)c2OC(c2cc(O)cc(OC)c2)C1c1cc(C)c(OC)c(OC)c1</smiles>

B

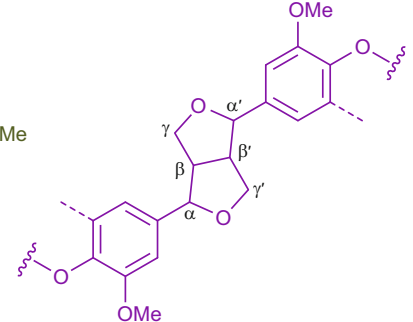

C

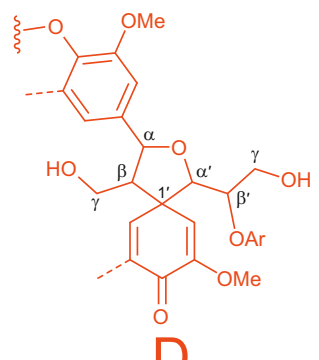<smiles>CCC(O)c1ccc(OC)c(OC)c1</smiles>

G<smiles>CCC(O)c1cc(OC)c(OC)c(OC)c1</smiles>

$\mathrm{S}$<smiles>[R]C(=O)c1cc(OC)c(OC)c(OC)c1</smiles>

$S^{\prime}$ corresponded to the benzenic rings of the $\mathrm{S}$ and $\mathrm{G}$ lignin units as shown for the whole wood spectrum. Signals from $\mathrm{C}_{\alpha^{-}}$ oxidized S-lignin units $\left(\mathrm{S}_{2,6}^{\prime}\right)$ were also observed. Some new signals not observed in the whole wood spectra appeared in this region corresponding to the above-mentioned spirodienone substructure (D) with $\mathrm{C}_{2^{\prime}}-\mathrm{H}_{2^{\prime}}$ and $\mathrm{C}_{6^{\prime}}-\mathrm{H}_{6^{\prime}}$
Table 2 Assignments of lignin main ${ }^{13} \mathrm{C}$ - ${ }^{1} \mathrm{H}$ correlation signals in the HSQC spectra of the whole wood, CEL, and filtrate samples (in DMSO- $d_{6}$ ). See Fig. 4 for chemical structures

\begin{tabular}{|c|c|c|}
\hline Label & $\delta_{\mathrm{C}} / \delta_{\mathrm{H}}(\mathrm{ppm})$ & Assignment \\
\hline $\mathrm{B}_{\beta}$ & $53.1 / 3.45$ & $\mathrm{C}_{\beta}-\mathrm{H}_{\beta}$ in phenylcoumaran substructures (B) \\
\hline $\mathrm{C}_{\beta}$ & $53.3 / 3.05$ & $\mathrm{C}_{\beta}-\mathrm{H}_{\beta}$ in $\beta-\beta^{\prime}$ resinol substructures $(\mathrm{C})$ \\
\hline $\mathrm{MeO}$ & $55.6 / 3.72$ & $\mathrm{C}-\mathrm{H}$ in methoxyls \\
\hline $\mathrm{A}_{\gamma}$ & $59.4 / 3.38$ and 3.70 & $\mathrm{C}_{\gamma}-\mathrm{H}_{\gamma}$ in $\beta-O-4^{\prime}$ structures (A) \\
\hline $\mathrm{D}_{\beta}$ & $59.7 / 2.73$ & $\mathrm{C}_{\beta}-\mathrm{H}_{\beta}$ in spirodienone substructures (D) \\
\hline $\mathrm{I}_{\gamma}$ & $61.3 / 4.08$ & $\mathrm{C}_{\gamma}-\mathrm{H}_{\gamma}$ in cinnamyl alcohol end-groups (I) \\
\hline $\mathrm{B}_{\gamma}$ & $62.6 / 3.67$ & $\mathrm{C}_{\gamma}-\mathrm{H}_{\gamma}$ in phenylcoumaran substructures (B) \\
\hline $\mathrm{A}_{\alpha}$ & $71.8 / 4.85$ & $\mathrm{C}_{\alpha}-\mathrm{H}_{\alpha}$ in $\beta-O-4^{\prime}$ structures (A) \\
\hline $\mathrm{C}_{\gamma}$ & $71.0 / 3.81$ and 4.18 & $\mathrm{C}_{\gamma}-\mathrm{H}_{\gamma}$ in $\beta-\beta^{\prime}$ resinol substructures (C) \\
\hline $\mathrm{D}_{\beta^{\prime}}$ & $79.2 / 4.10$ & $\mathrm{C}_{\beta^{\prime}}-\mathrm{H}_{\beta^{\prime}}$ in spirodienone substructures (D) \\
\hline $\mathrm{D}_{\alpha}$ & $81.0 / 5.08$ & $\mathrm{C}_{\alpha}-\mathrm{H}_{\alpha}$ in spirodienone substructures (D) \\
\hline$A_{o x \beta}$ & $83.0 / 5.20$ & $\mathrm{C}_{\beta}-\mathrm{H}_{\beta}$ in $\alpha$-oxidized $\beta$-O-4' substructures $\left(\mathrm{A}_{\mathrm{ox}}\right)$ \\
\hline$A_{\beta(G)}$ & $83.6 / 4.28$ & $\mathrm{C}_{\beta}-\mathrm{H}_{\beta}$ in $\beta-O-4^{\prime}$ structures (A) linked to a $\mathrm{G}$ unit \\
\hline $\mathrm{D}_{\alpha^{\prime}}$ & $83.7 / 4.68$ & $\mathrm{C}_{\alpha^{\prime}}-\mathrm{H}_{\alpha^{\prime}}$ in spirodienone substructures (D) \\
\hline $\mathrm{C}_{\alpha}$ & $84.7 / 4.64$ & $\mathrm{C}_{\alpha}-\mathrm{H}_{\alpha}$ in $\beta-\beta^{\prime}$ resinol substructures $(\mathrm{C})$ \\
\hline $\mathrm{A}_{\beta(\mathrm{S})}$ & $85.7 / 4.10$ & $\mathrm{C}_{\beta}-\mathrm{H}_{\beta}$ in $\beta-O-4^{\prime}$ structures (A) linked to a $\mathrm{S}$ unit \\
\hline $\mathrm{B}_{\alpha}$ & $86.4 / 5.43$ & $\mathrm{C}_{\alpha}-\mathrm{H}_{\alpha}$ in phenylcoumaran substructures (B) \\
\hline $\mathrm{S}_{2,6}$ & $103.9 / 6.69$ & $\mathrm{C}_{2}-\mathrm{H}_{2}$ and $\mathrm{C}_{6}-\mathrm{H}_{6}$ in syringyl units (S) \\
\hline $\mathrm{S}_{2,6}^{\prime}$ & $106.1 / 7.31$ & $\mathrm{C}_{2}-\mathrm{H}_{2}$ and $\mathrm{C}_{6}-\mathrm{H}_{6}$ in $\alpha$-oxidized syringyl units $\left(\mathrm{S}^{\prime}\right)$ \\
\hline $\mathrm{G}_{2}$ & $110.8 / 6.96$ & $\mathrm{C}_{2}-\mathrm{H}_{2}$ in guaiacyl units $(\mathrm{G})$ \\
\hline $\mathrm{D}_{2}$ & $113.3 / 6.25$ & $\mathrm{C}_{2}-\mathrm{H}_{2}$ in spirodienone substructures (D) \\
\hline $\mathrm{G}_{5} / \mathrm{G}_{6}$ & $114.3 / 6.69$ and $114.9 / 6.94$ & $\mathrm{C}_{5}-\mathrm{H}_{5}$ and $\mathrm{C}_{6}-\mathrm{H}_{6}$ in guaiacyl units $(\mathrm{G})$ \\
\hline $\mathrm{G}_{6}$ & $118.8 / 6.78$ & $\mathrm{C}_{6}-\mathrm{H}_{6}$ in guaiacyl units $(\mathrm{G})$ \\
\hline $\mathrm{D}_{6}$ & $118.7 / 6.06$ & $\mathrm{C}_{6}-\mathrm{H}_{6}$ in spirodienone substructures (D) \\
\hline
\end{tabular}


Fig. 5 HSQC NMR spectra of CEL preparations isolated from eucalypt wood samples from a multistage enzymatic sequence, including four treatments with M. thermophila laccase-MeS and four alkaline peroxide extractions: $\mathbf{a}$ and $\mathbf{b}$ controls of first and fourth cycle of enzymatic pretreatment (stages 2 and 8, respectively); c and $\mathbf{d}$ samples from first and fourth cycle of enzymatic pretreatment with laccase alone (stages 2 and 8, respectively); $\mathbf{e}$ and $\mathbf{f}$ samples from first and fourth cycle of enzymatic pretreatment with laccase-MeS (stages 2 and 8, respectively). See Table 2 for signal assignment, Table 3 for quantification of the lignin structures identified, and Fig. 4 for the main lignin structures identified
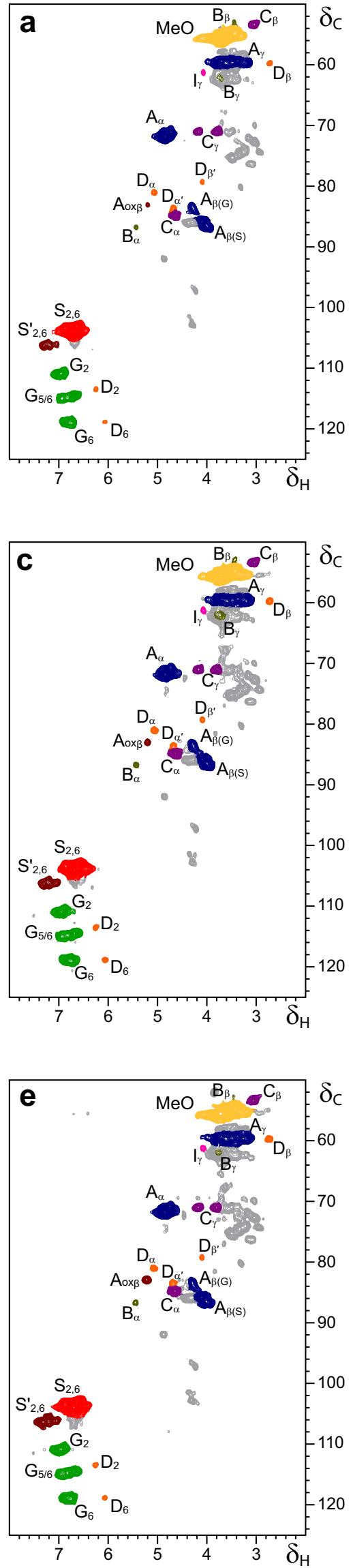
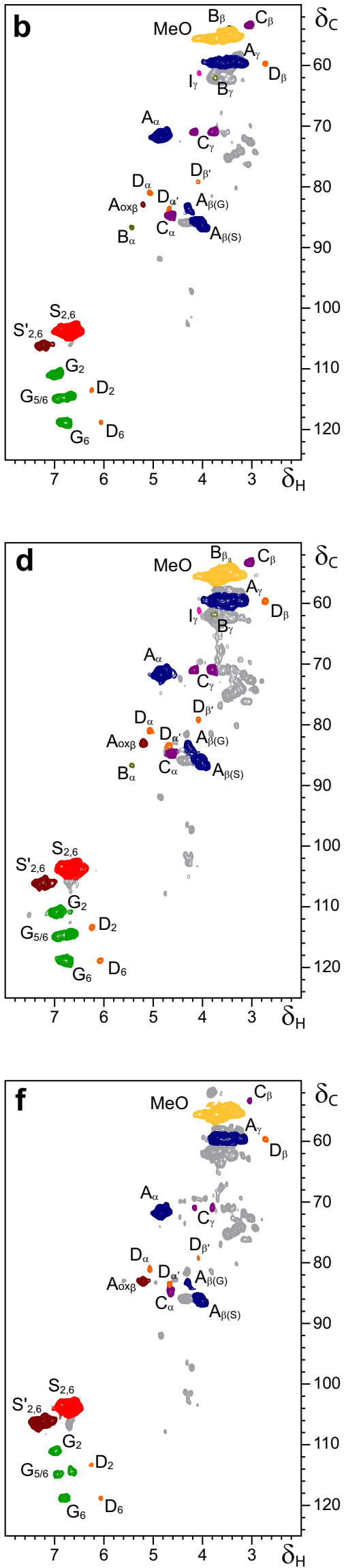
correlations $\left(\mathrm{D}_{2^{\prime}}\right.$ and $\left.\mathrm{D}_{6^{\prime}}\right)$. Most of the lignin side chains in control samples were barely modified along the sequence as shown in Table 3 for resinol, spirodienones, and $\beta-O-4^{\prime}$ alkylaryl ether substructures. Only the phenylcoumarans decreased from cycles 1 to 4 . The most remarkable effect of the control pretreatment conditions was the increase in the $\mathrm{S} / \mathrm{G}$ ratio from 3.6 (stage 2) to 4.3 (stage 8 ) in agreement with that observed with the whole control samples.

The HSQC spectra of isolated lignins from the eucalypt samples after enzymatic pretreatment with $M$. thermophila laccase and MeS (stages 2 and 8) are shown in Fig. 5e, f and the main differences in lignin units and inter-unit linkages, compared with the previous samples, are shown in Table 3. Concerning lignin composition, the most noticeable effect of the enzymatic treatments on the residual lignin remaining in wood was the significant reduction in $\mathrm{G}$ units produced by the laccase-mediator treatment resulting in an increase of the $\mathrm{S} / \mathrm{G}$ ratio from 5.0 (stage 2) to 13.8 (stage 8). Additionally, a strong increase in $\mathrm{C}_{\alpha}$-oxidized $\mathrm{S}$ units was produced, as shown in Table 3, where the contribution of MeS to the lignin $\mathrm{S}_{2,6}^{\prime}$ signal at 106/7.3 ppm was deduced. The increase of the $S_{2,6}^{\prime}$ aromatic signal was accompanied by an increase in the $\mathrm{C}_{\beta}-\mathrm{H}_{\beta}$ correlations signal from $\beta-O-4$ ' ether linked $\mathrm{C}_{\alpha}$-oxidized side chains $\left(\mathrm{A}_{\mathrm{ox} \beta}\right)$. Moreover, a significant decrease in $\beta-O-4^{\prime}$ alkyl-aryl ether (A) and resinol substructures (C) per 100 phenylpropane units was the main effect observed in the side-chain region of the HSQC spectra of the lignin isolated from the wood treated with laccase and MeS, together with a decrease in the less intense signals of phenylcoumarans and spirodienones, which was especially evident in stage 8 . This suggests a more degraded lignin than that present in control samples.

The 2D NMR analysis of lignin isolated from eucalypt samples pretreated with laccase alone (Fig. 5c, d) also revealed some differences with respect to the control. Interestingly, the most remarkable effect is the increase of oxidized lignin structures evidenced by both aromatic $\left(\mathrm{S}_{2,6}^{\prime}\right)$ and aliphatic side-chains $\left(A_{o x \beta}\right)$ signals (Table 3 ) revealing that laccase alone attack lignin by a mechanism similar to that of the laccase-mediator system. On the other hand, in these samples a decrease in $\beta-O-4^{\prime}$ alkyl-aryl ether (A), spirodienones (D), and resinol substructures (C) was not observed in the side-chain region of the HSQC spectrum contrary to the laccase-mediator-treated samples. This could be indicative of an oxidized lignin but less degraded than lignin in samples after laccase-mediator treatment.

2D NMR Analyses of the Filtrates from the Pretreatment Sequence

The filtrates obtained after each of the eight steps of the multistage sequence were freeze-dried and analyzed by $2 \mathrm{D}$ NMR to identify the degradation products of wood lignin after
Table 3 Lignin units ( $\mathrm{S}, \mathrm{G}$, and $\mathrm{S}^{\prime}$ molar percentages) and inter-unit linkages (side-chains per 100 phenylpropanoid units) from the HSQC spectra of CEL samples from eucalypt wood at two stages (2 and 8) of a multistage sequence, including four treatments with $M$. thermophila laccase-MeS and 4 alkaline peroxide extractions, compared with a control without enzyme, a treatment with laccase alone and CEL from initial eucalypt wood

\begin{tabular}{|c|c|c|c|}
\hline & \multirow[b]{2}{*}{$\begin{array}{l}\text { Initial } \\
\text { wood }\end{array}$} & \multicolumn{2}{|l|}{ CEL } \\
\hline & & $\begin{array}{l}\text { Stage } \\
2\end{array}$ & $\begin{array}{l}\text { Stage } \\
8\end{array}$ \\
\hline \multicolumn{4}{|l|}{ Control } \\
\hline \multicolumn{4}{|l|}{ Lignin units } \\
\hline Syringyl (S) (\% total) & 77 & 78 & 81 \\
\hline Guaiacyl $(\mathrm{G})(\%$ total $)$ & 23 & 22 & 19 \\
\hline $\mathrm{C} \alpha$-oxidized $\mathrm{S}$ units $\left(\mathrm{S}^{\prime}\right)(\% \mathrm{~S})$ & 6 & 8 & 10 \\
\hline $\mathrm{S} / \mathrm{G}$ ratio & 3.4 & 3.6 & 4.3 \\
\hline \multicolumn{4}{|l|}{ Inter-unit linkages and end-groups } \\
\hline$\beta-O-4^{\prime}$ alkyl-aryl ethers $(\mathrm{A})(\% \mathrm{~S}+\mathrm{G})$ & 58 & 62 & 63 \\
\hline Phenylcoumarans (B) (\% S+G) & 2 & 2 & 1 \\
\hline Resinols $(\mathrm{C})(\% \mathrm{~S}+\mathrm{G})$ & 9 & 8 & 8 \\
\hline Spirodienones (D) $(\% \mathrm{~S}+\mathrm{G})$ & 2 & 2 & 2 \\
\hline Total $(\% \mathrm{~S}+\mathrm{G})$ & 71 & 73 & 75 \\
\hline $\mathrm{C}_{\alpha}$-oxidized $\beta-O-4^{\prime}$ ethers $\left(\mathrm{A}_{\mathrm{ox}}\right)(\% \mathrm{~A})$ & 2 & 2 & 2 \\
\hline \multicolumn{4}{|l|}{ M. thermophila laccase } \\
\hline \multicolumn{4}{|l|}{ Lignin units } \\
\hline Syringyl (S) (\% total) & & 80 & 83 \\
\hline Guaiacyl (G) (\% total) & & 20 & 17 \\
\hline $\mathrm{C} \alpha$-oxidized $\mathrm{S}$ units $\left(\mathrm{S}^{\prime}\right)(\% \mathrm{~S})$ & & 10 & 17 \\
\hline $\mathrm{S} / \mathrm{G}$ ratio & & 3.9 & 4.8 \\
\hline \multicolumn{4}{|l|}{ Inter-unit linkages and end-groups } \\
\hline$\beta-O-4^{\prime}$ alkyl-aryl ethers $(\mathrm{A})(\% \mathrm{~S}+\mathrm{G})$ & & 60 & 58 \\
\hline Phenylcoumarans (B) $(\% \mathrm{~S}+\mathrm{G})$ & & 2 & 1 \\
\hline Resinols $(\mathrm{C})(\% \mathrm{~S}+\mathrm{G})$ & & 7 & 6 \\
\hline Spirodienones (D) $(\% \mathrm{~S}+\mathrm{G})$ & & 2 & 2 \\
\hline Total $(\% \mathrm{~S}+\mathrm{G})$ & & 71 & 68 \\
\hline $\mathrm{C}_{\alpha}$-oxidized $\beta-O-4^{\prime}$ ethers $\left(\mathrm{A}_{\mathrm{ox}}\right)(\% \mathrm{~A})$ & & 2 & 5 \\
\hline \multicolumn{4}{|l|}{ M. thermophila laccase-MeS } \\
\hline \multicolumn{4}{|l|}{ Lignin units } \\
\hline Syringyl (S) (\% total) & & 83 & 93 \\
\hline Guaiacyl (G) (\% total) & & 17 & 7 \\
\hline $\mathrm{C} \alpha$-oxidized $\mathrm{S}$ units $\left(\mathrm{S}^{\prime}\right)(\% \mathrm{~S})$ & & 15 & 34 \\
\hline $\mathrm{S} / \mathrm{G}$ ratio & & 5.0 & 13.8 \\
\hline \multicolumn{4}{|l|}{ Inter-unit linkages and end-groups } \\
\hline$\beta-O-4^{\prime}$ alkyl-aryl ethers $(\mathbf{A})(\% \mathrm{~S}+\mathrm{G})$ & & 59 & 51 \\
\hline Phenylcoumarans (B) (\% S+G) & & 2 & 0 \\
\hline Resinols $(\mathrm{C})(\% \mathrm{~S}+\mathrm{G})$ & & 7 & 2 \\
\hline Spirodienones (D) $(\% \mathrm{~S}+\mathrm{G})$ & & 2 & 1 \\
\hline Total $(\% \mathrm{~S}+\mathrm{G})$ & & 70 & 55 \\
\hline $\mathrm{C}_{\alpha}$-oxidized $\beta-O-4^{\prime}$ ethers $\left(\mathrm{A}_{\mathrm{ox}}\right)(\% \mathrm{~A})$ & & 5 & 13 \\
\hline
\end{tabular}

both enzymatic and alkaline peroxide extraction stages. Table 4 shows the lignin composition of filtrates after the first 
Table 4 Lignin units (, $\mathrm{G}$, and $\mathrm{S}^{\prime}$ molar percentages) and inter-unit linkages (side-chains per 100 phenylpropanoid units) from the HSQC spectra of the filtrates from eucalypt wood pretreatment at two stages (2 and 8) of a multistage sequence, including four treatments with M. thermophila laccase-MeS and four alkaline peroxide extractions, compared with a control without enzyme and a treatment with laccase alone

Filtrates

Stage $2 \quad$ Stage 8

\section{Control}

Lignin units

Syringyl (S) (\% total)
Guaiacyl $(\mathrm{G})(\%$ total $)$
C $\alpha$-oxidized S units $\left(\mathrm{S}^{\prime}\right)(\% \mathrm{~S})$
S/G ratio

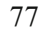

23

Lignin inter-unit linkages $(\% \mathrm{~S}+\mathrm{G})$

$\beta-O-4^{\prime}$ alkyl-aryl ethers (A)

Phenylcoumarans (B)

Resinols (C)

Spirodienones (D)

$\mathrm{C}_{\alpha}$-oxidized $\beta-O-4^{\prime}$ ethers $\left(\mathrm{A}_{\mathrm{ox}}\right)(\% \mathrm{~A})$

Total

M. thermophila laccase

Lignin units

Syringyl (S) (\% total)

Guaiacyl (G) (\% total)

$\mathrm{C} \alpha$-oxidized $\mathrm{S}$ units $\left(\mathrm{S}^{\prime}\right)(\% \mathrm{~S})$

$\mathrm{S} / \mathrm{G}$ ratio

Lignin inter-unit linkages $(\% \mathrm{~S}+\mathrm{G})$

$\beta-O-4^{\prime}$ alkyl-aryl ethers (A)

Phenylcoumarans (B)

Resinols (C)

Spirodienones (D)

$\mathrm{C}_{\alpha}$-oxidized $\beta-O-4^{\prime}$ ethers $\left(\mathrm{A}_{\mathrm{ox}}\right)(\% \mathrm{~A})$

Total

M. thermophila laccase-MeS

Lignin units

$\begin{array}{lll}\text { Syringyl (S) (\% total) } & 91 & 96 \\ \text { Guaiacyl }(\mathrm{G})(\% \text { total) } & 9 & 4 \\ \mathrm{C} \alpha \text {-oxidized S units }\left(\mathrm{S}^{\prime}\right)(\% \mathrm{~S}) & 47 & 41 \\ \mathrm{~S} / \mathrm{G} \text { ratio } & 10.4 & 24.3 \\ \text { ignin inter-unit linkages }(\% \mathrm{~S}+\mathrm{G}) & & \\ \beta-O-4^{\prime} \text { alkyl-aryl ethers (A) } & 39 & 32 \\ \text { Phenylcoumarans (B) } & 1 & 0 \\ \text { Resinols }(\mathrm{C}) & 5 & 0 \\ \text { Spirodienones (D) } & 2 & 0 \\ \mathrm{C}_{\alpha} \text {-oxidized } \beta-O-4^{\prime} \text { ethers }\left(\mathrm{A}_{\mathrm{ox}}\right)(\% \mathrm{~A}) & 2 & 0 \\ \text { Total } & 47 & 32\end{array}$

(stage 2) and last cycle (stage 8) of pretreatment and Fig. 6 shows the HSQC spectra of these filtrates. In addition to lignin, signals of carbohydrate (xylan) were also observed in the spectra. Comparing the characteristics of lignin in filtrates from stages 2 and 8, it can be observed that in control samples the $\mathrm{S} / \mathrm{G}$ ratio increased and the percentage of inter-unit linkages identified in the HSQC spectra decreased from 73 to 69. This decrease was mainly due to the removal of phenylcoumarans, resinols and spirodienones substructures whereas the $\beta-O-4^{\prime}$ alkyl-aryl ether linkages remained. The increase in the $\mathrm{S} / \mathrm{G}$ ratio and the loss of phenylcoumarans, resinols, and spirodienones substructures from stages 2 to 8 was also observed in the lignin present in filtrates from laccase alone and laccase-mediator treatments. In contrast to control samples, a decrease in $\beta-O-4^{\prime}$ alkyl-aryl ether linkages was observed in the lignin present in filtrates from enzymatically treated samples. Also, a strong increase in $\mathrm{C}_{\alpha}$-oxidized $\mathrm{S}$ units was produced in the latter samples. It should be mentioned that in the spectra of filtrates from enzymatic stages $(1,3,5$, and 7) (data not shown) the presence of lignin signals were minor compared to alkaline peroxide stages $(2,4,6$, and 8$)$ with syringyl units predominating.

\section{Lignin Modification Along the P. cinnabarinus Laccase-HBT Pretreatment}

Lignin modification during the pretreatment of eucalypt wood with a high redox potential laccase and mediator along a multistage sequence similar to that described above was also studied by 2D NMR with the objective of comparing the results with those obtained in the pretreatment of eucalypt wood with low redox potential laccase and mediator. With this purpose, 2D NMR analyses of whole eucalypt samples (swollen in DMSO- $d_{6}$ ) after one and four cycles of pretreatment (stages 2 and 8 , respectively) with $P$. cinnabarinus laccase in the presence of the synthetic mediator HBT were carried out (Fig. 7), and the lignin composition and percentages of inter-unit linkages in the whole samples are shown in Table 5. The qualitative composition in aromatic units and lignin inter-unit linkages of the residual lignins present in eucalypt wood after the whole sequence (stage 8) with the high and low redox potential laccases and their corresponding mediators was similar. Both HSQC spectra were characterized by the presence of syringyl units and the absence of guaiacyl ones. A considerable part of the syringyl units were oxidized in the $\mathrm{C}_{\alpha}$, reaching 47 and $87 \%$ of total syringyl units in samples pretreated with $M$. thermophila-MeS and $P$. cinnabarinus-HBT, respectively. Likewise, the only interunit linkages present in these two lignins were the $\beta-O-4^{\prime}$ alkyl-aryl ether linkages although the proportions of these linkages were higher in the $M$. thermophila-MeS pretreated samples (24 per 100 phenylpropane units) than in the P. cinnabarinus-HBT ones (14 per 100 phenylpropane units). These results indicate that the latter lignin was more depolymerized and oxidized than the former. Similar 
Fig. 6 HSQC NMR spectra of lignins from filtrates obtained from a multistage enzymatic sequence, including four treatments with $M$. thermophila laccase-MeS and four alkaline peroxide extractions: $\mathbf{a}$ and $\mathbf{b}$ controls of first and fourth cycle of enzymatic pretreatment (stages 2 and 8, respectively); $\mathbf{c}$ and $\mathbf{d}$ samples from first and fourth cycle of enzymatic pretreatment with laccase alone (stages 2 and 8 , respectively); e and $\mathbf{f}$ samples from first and fourth cycle of enzymatic pretreatment with laccase-MeS (stages 2 and 8, respectively). See Table 2 for signal assignment, Table 4 for quantification of the lignin structures identified, and Fig. 4 for the main lignin structures identified
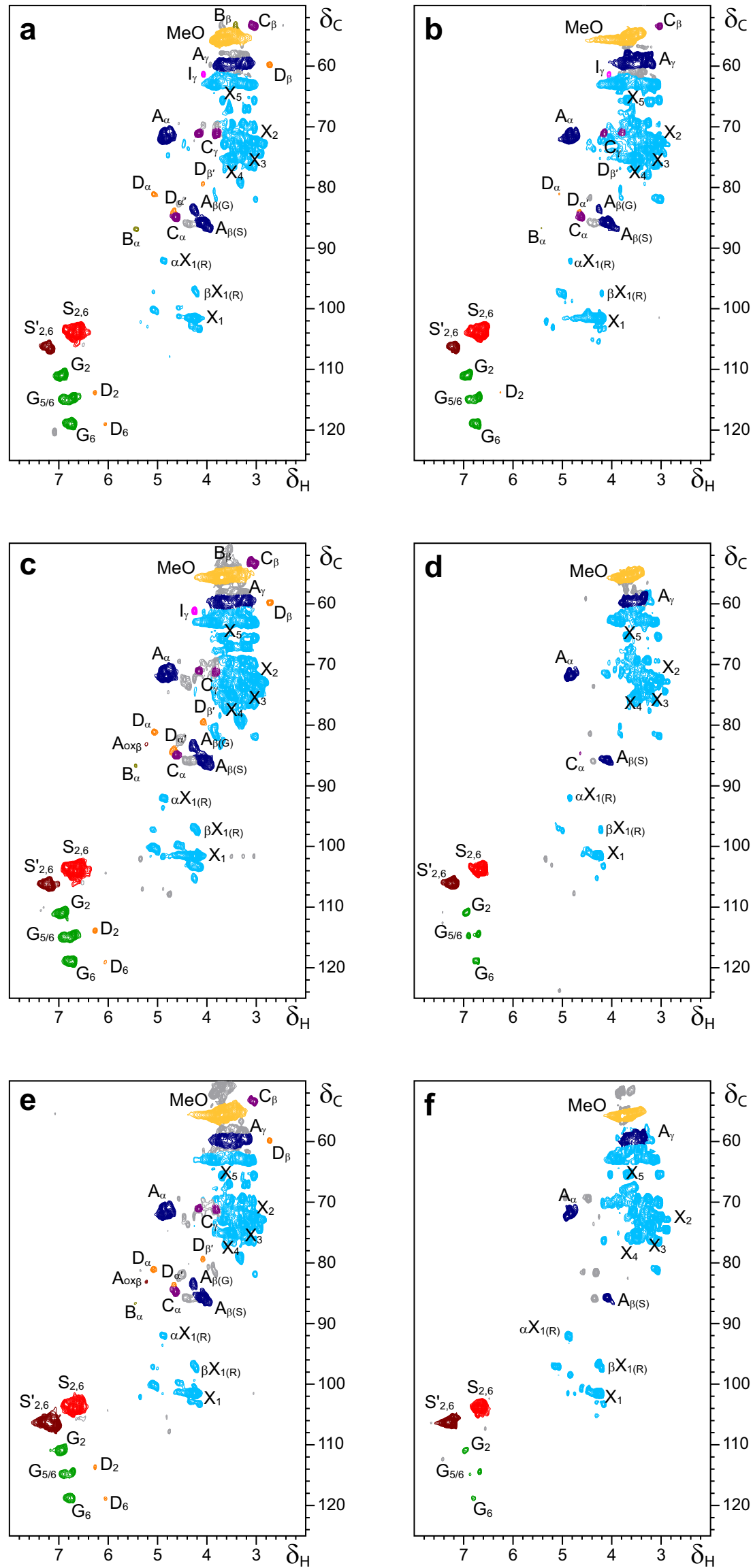
Fig. 7 HSQC NMR spectra of whole eucalypt wood (swollen in dimethylsulfoxide- $d_{6}$ ), from a multistage enzymatic sequence, including four treatments with $P$. cinnabarinus laccase-HBT and four alkaline peroxide extractions: $\mathbf{a}$ and $\mathbf{b}$ controls of first and fourth cycle of enzymatic pretreatment (stages 2 and 8 , respectively); c and $\mathbf{d}$ samples from first and fourth cycle of enzymatic pretreatment with laccase alone (stages 2 and 8, respectively); $\mathbf{e}$ and $\mathbf{f}$ samples from first and fourth cycle of enzymatic pretreatment with laccase and mediator (stages 2 and 8 , respectively). See Table 2 for signal assignment, Table 5 for quantification of the lignin structures identified, and Fig. 4 for the main lignin structures identified
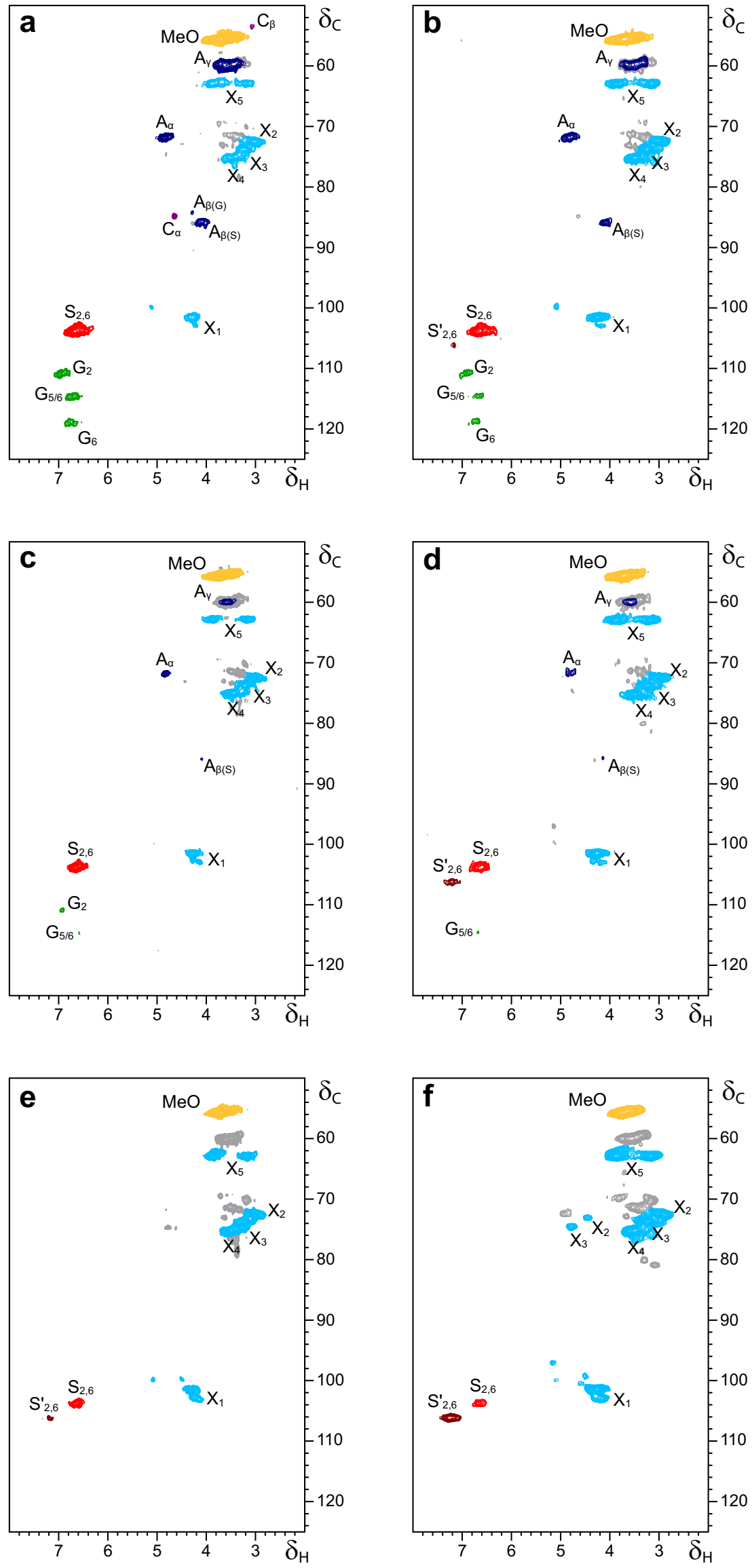
Table 5 Lignin units (S, G, and $\mathrm{S}^{\prime}$ molar percentages) and inter-unit linkages (side-chains per 100 phenylpropanoid units) from the HSQC spectra of eucalypt samples at two stages (2 and 8$)$ of a multistage sequence, including four enzymatic treatments with $P$. cinnabarinus laccase and HBT and four alkaline peroxide extractions, compared with a control without enzyme and a treatment with laccase alone

\begin{tabular}{|c|c|c|}
\hline & \multicolumn{2}{|c|}{ Whole wood } \\
\hline & Stage 2 & Stage 8 \\
\hline \multicolumn{3}{|l|}{ Control } \\
\hline \multicolumn{3}{|l|}{ Lignin units (\%) } \\
\hline $\mathrm{S}(\% \mathrm{~S}+\mathrm{G})$ & 71 & 79 \\
\hline $\mathrm{G}(\% \mathrm{~S}+\mathrm{G})$ & 29 & 21 \\
\hline $\mathrm{S}^{\prime}(\% \mathrm{~S})$ & 2 & 5 \\
\hline $\mathrm{S} / \mathrm{G}$ & 2.4 & 3.8 \\
\hline \multicolumn{3}{|l|}{ Lignin inter-unit linkages $(\%)$} \\
\hline$\beta-O-4^{\prime}$ alkyl-aryl ethers $(\mathrm{A})(\% \mathrm{~S}+\mathrm{G})$ & 39 & 43 \\
\hline Phenylcoumarans (B) $(\% \mathrm{~S}+\mathrm{G})$ & 0 & 0 \\
\hline Resinols $(\mathrm{C})(\% \mathrm{~S}+\mathrm{G})$ & 7 & 8 \\
\hline Spirodienones $(\mathrm{F})(\% \mathrm{~S}+\mathrm{G})$ & 0 & 0 \\
\hline Total $(\% \mathrm{~S}+\mathrm{G})$ & 46 & 50 \\
\hline \multicolumn{3}{|l|}{ P. cinnabarinus laccase } \\
\hline \multicolumn{3}{|l|}{ Lignin units (\%) } \\
\hline $\mathrm{S}(\% \mathrm{~S}+\mathrm{G})$ & 86 & 95 \\
\hline $\mathrm{G}(\% \mathrm{~S}+\mathrm{G})$ & 14 & 5 \\
\hline $\mathrm{S}^{\prime}(\% \mathrm{~S})$ & 4 & 28 \\
\hline $\mathrm{S} / \mathrm{G}$ & 6.2 & 17.5 \\
\hline \multicolumn{3}{|l|}{ Lignin inter-unit linkages $(\%)$} \\
\hline$\beta-O-4^{\prime}$ alkyl-aryl ethers $(\mathrm{A})(\% \mathrm{~S}+\mathrm{G})$ & 26 & 31 \\
\hline Phenylcoumarans (B) $(\% \mathrm{~S}+\mathrm{G})$ & 0 & 0 \\
\hline Resinols $(\mathrm{C})(\% \mathrm{~S}+\mathrm{G})$ & 4 & 0 \\
\hline Spirodienones $(\mathrm{F})(\% \mathrm{~S}+\mathrm{G})$ & 0 & 0 \\
\hline Total $(\% \mathrm{~S}+\mathrm{G})$ & 30 & 31 \\
\hline \multicolumn{3}{|l|}{ P. cinnabarinus laccase-HBT } \\
\hline \multicolumn{3}{|l|}{ Lignin units (\%) } \\
\hline $\mathrm{S}(\% \mathrm{~S}+\mathrm{G})$ & 100 & 100 \\
\hline $\mathrm{G}(\% \mathrm{~S}+\mathrm{G})$ & 0 & 0 \\
\hline $\mathrm{S}^{\prime}(\% \mathrm{~S})$ & 29 & 62 \\
\hline $\mathrm{S} / \mathrm{G}$ & - & - \\
\hline \multicolumn{3}{|l|}{ Lignin inter-unit linkages $(\%)$} \\
\hline$\beta-O-4^{\prime}$ alkyl-aryl ethers (A) $(\% \mathrm{~S}+\mathrm{G})$ & 19 & 14 \\
\hline Phenylcoumarans (B) $(\% \mathrm{~S}+\mathrm{G})$ & 0 & 0 \\
\hline Resinols $(\mathrm{C})(\% \mathrm{~S}+\mathrm{G})$ & 0 & 0 \\
\hline Spirodienones $(\mathrm{F})(\% \mathrm{~S}+\mathrm{G})$ & 0 & 0 \\
\hline Total $(\% \mathrm{~S}+\mathrm{G})$ & 19 & 14 \\
\hline
\end{tabular}

tendencies were also obtained in the last stage of pretreatment of eucalypt wood with the two laccases alone (without mediator). In both cases, the $\beta-O-4^{\prime}$ linkages were the only interunit linkages observed in the HSQC spectra, representing a higher percentage in M. thermophila (43 per 100 phenylpropane units) than in P. cinnabarinus laccase (31 per 100 phenylpropane units). Likewise, lignins from both treatments were constituted mainly by syringyl units some of them being $\mathrm{C}_{\alpha}$-oxidized $\mathrm{S}$ units $\left(\mathrm{S}^{\prime}\right)$ with higher predominance in P. cinnabarinus laccase (28\%) than in M. thermophila $(16 \%)$. In addition, a relative low proportion of guaiacyl units were present in both lignins. The above results show that in spite of some quantitative differences, both laccase mediator pretreatments modify lignin composition in a similar way after the whole multistage sequence.

Additionally, modification of eucalypt wood lignin with these two laccase-mediator systems was also compared at the beginning of the sequence (after one cycle of treatment). The 2D NMR analyses of the whole samples revealed substantial differences between the two different laccase-mediator pretreatments at stage 2 . The HSQC spectrum of the eucalypt wood pretreated with $P$. cinnabarinus laccase and HBT (Fig. 7e) showed a radically smaller amounts of lignin signals compared with that of $M$. thermophila-MeS (Fig. 3c) as revealed by the different amount of lignin inter-unit linkages per 100 phenylpropane units accounting for 19 and 54, respectively (Table 5) indicating that the former lignin was more degraded than the latter. Indeed, lignin from the P. cinnabarinus-HBT treatment is almost as degraded after the first cycle (19 per 100 phenylpropane units) as after the fourth one (14 per 100 phenylpropane units) unlike lignin from M. thermophila-MeS treatment. The main differences between lignins from both treatments at stage 2 relay on the composition in aromatic units that in the case of P. cinnabarinus-HBT treatment is constituted only by syringyl units while in the case of $M$. thermophila-MeS one is constituted by syringyl and guaiacyl ones. On the other hand, interunit linkages present in lignin from the latter treatment include both $\beta-O-4^{\prime}$ linkages and resinol substructures while lignin units from the former treatment are linked only by $\beta-O-4^{\prime}$ linkages.

The HSQC spectrum of the eucalypt wood pretreated with P. cinnabarinus laccase alone (Fig. 7c) (stage 2) also showed very smaller amounts of lignin signals compared with that of M. thermophila (Fig. 2c). Likewise, lignins from both treatments showed different amount of inter-unit linkages accounting for 30 and 59 per 100 phenylpropane units, respectively (Table 5) indicating that the former lignin was more degraded than the latter. Like in the case of laccase-mediator systems, lignin from the $P$. cinnabarinus treatment is equally degraded after the first and fourth cycle (about 30 per 100 phenylpropane units) unlike lignin from $M$. thermophila treatment (Table 1). With regard to lignin composition, samples from $P$. cinnabarinus and $M$. thermophila laccase treatment contained syringyl and guaiacyl units although in different proportions (S/G ratios of 6.2 and 3.5, respectively). Lignin inter-unit linkages included both $\beta-O-4^{\prime}$ linkages and resinol substructures in both treatments, resinol amounts being 
similar in both lignins while $\beta-O-4^{\prime}$ linkages representing a higher amount in the $M$. thermophila laccase treatment.

Saccharification of Wood Pretreated with two Laccase-Mediator Systems

In addition to studying in detail the structural modification of lignin from eucalypt wood during the pretreatment with two different laccase-mediator systems in a multistage sequence consisting of four cycles (eight stages), the effect of these treatments on lignin content and saccharification yields after enzymatic hydrolysis was studied. Table 6 shows the lignin content (as Klason lignin) and the content of glucose and xylose released after the enzymatic hydrolysis with cellulases of eucalypt samples pretreated with the M. thermophila and P. cinnabarinus laccases (data after first and last cycles of the sequence). The pretreatment of eucalypt wood with M. thermophila-MeS and P. cinnabarinus-HBT produced a decrease in lignin content after the four cycles of about $50 \%$ in both cases. This decrease in lignin content paralleled the increase in enzymatic saccharification yield of glucose of almost $30 \%$ with both pretreatments. Therefore, both laccase-mediator systems produced similar effects with regard

Table 6 Lignin content (as Klason lignin) and monosaccharide release (both as percentage of sample weight) from cellulase hydrolysis of eucalypt samples from cycles 1 and 4 of a multistage sequence, including four enzymatic treatments with $M$. thermophila-MeS or P. cinnabarinus laccases-HBT and four alkaline peroxide extractions, compared with a control without enzyme, a treatment with laccase alone, and the initial eucalypt wood. Means \pm SD (from triplicates)

\begin{tabular}{llll}
\hline & Lignin (\%) & Glucose (\%) & Xylose (\%) \\
\hline Initial eucalypt wood & $22.3 \pm 0.3$ & $39.5 \pm 1.1$ & $6.7 \pm 0.1$ \\
$\begin{array}{l}\text { M. thermophila laccase } \\
\text { 1 Cycle }\end{array}$ & & & \\
$\quad$ Control & $21.2 \pm 0.8$ & $39.7 \pm 0.2$ & $6.7 \pm 0.1$ \\
$\quad$ Laccase & $21.1 \pm 0.9$ & $39.5 \pm 0.7$ & $6.6 \pm 0.2$ \\
$\quad$ Laccase-MeS & $21.1 \pm 0.8$ & $39.7 \pm 0.4$ & $6.5 \pm 0.3$ \\
4 Cycles & & & \\
Control & $21.1 \pm 1.0$ & $43.7 \pm 0.2$ & $7.5 \pm 0.1$ \\
Laccase & $16.8 \pm 0.3$ & $47.8 \pm 1.2$ & $8.1 \pm 0.2$ \\
$\quad$ Laccase-MeS & $11.2 \pm 0.3$ & $55.7 \pm 0.4$ & $9.1 \pm 0.1$ \\
P. cinnabarinus laccase & & & \\
1 Cycle & & & \\
$\quad$ Control & $19.5 \pm 0.9$ & $39.6 \pm 0.1$ & $6.7 \pm 0.0$ \\
$\quad$ Laccase & $19.5 \pm 0.9$ & $39.9 \pm 0.2$ & $6.7 \pm 0.0$ \\
Laccase-HBT & $16.8 \pm 0.9$ & $42.9 \pm 0.6$ & $7.7 \pm 0.1$ \\
4 Cycles & & & \\
Control & $17.9 \pm 0.9$ & $45.6 \pm 0.7$ & $8.3 \pm 0.1$ \\
Laccase & $17.9 \pm 0.9$ & $47.4 \pm 0.7$ & $8.2 \pm 0.1$ \\
Laccase-HBT & $9.6 \pm 1.0$ & $58.0 \pm 0.2$ & $7.6 \pm 0.1$ \\
\hline
\end{tabular}

to lignin content and glucose release after the four cycles of pretreatment. Surprisingly, the pretreatment with the two laccases alone produced different effects. Whereas the pretreatment of eucalypt wood with the low redox potential laccase from $M$. thermophila produced a decrease of lignin content of about $20 \%$, the pretreatment with the high redox potential laccase from $P$. cinnabarinus did not affect the lignin content. Concerning glucose release, the treatments with M. thermophila and P. cinnabarinus laccases alone produced an increase of glucose release of 9 and $4 \%$, respectively.

Unlike at the end of the sequence, considerable differences were observed between the two laccase-mediator treatments after the first cycle of pretreatment. While the pretreatment with $M$. thermophila-MeS did not produce any effect in lignin content (or glucose release), that with $P$. cinnabarinus-HBT decreased the lignin content in $14 \%$ and increase the glucose release by $8 \%$. On the other hand, the lignin content and saccarification yield with both laccases alone were not modified after the first cycle of pretreatment.

\section{Discussion}

Eucalypt is a rapidly growing and high biomass-producing tree used as a raw material for paper pulp manufacturing in several countries including Southwest Europe, Brazil, Uruguay, and South Africa. Among the different eucalypt species, wood from E. globulus is the best raw material for kraft pulp manufacturing due to the high pulp yield [25]. Additionally, the lignin of E. globulus is enriched in S units with $\beta-O-4^{\prime}$ linkages predominating [25-27]. This implies linear chains with less cross-linking than G-rich lignin because of the methoxylated and thereby, blocked C-5 position in the syringyl unit, being advantageous for delignification purposes. Additionally, the higher occurrence of $\beta-\beta$ units (resinols) observed in S-rich lignin [26] leads to shorter chain lengths and thus, lower molecular weights [28]. With all these characteristics, E. globulus wood has great potential as lignocellulosic feedstock for the production of second generation wood-based bioethanol [29]. However, as a lignocellulosic raw material, a pretreatment of eucalypt wood to overcome its recalcitrance toward enzymatic hydrolysis (mainly due to the presence of lignin) is required. After the first studies showing the potential of $M$. thermophila laccase-MeS pretreatment, followed by alkaline peroxide extraction in a multistage sequence, to remove lignin from eucalypt (E. globulus) feedstock improving saccharification after enzymatic hydrolysis [19], an interest arouse to deepen in the study of the modification of lignin structure along the complete sequence since lignin removal and its structure after pretreatment are crucial to promote fiber structure disruption and facilitate enzymatic hydrolysis. With this aim, samples of whole 
eucalypt material, their isolated lignins and filtrates at each stage of the whole sequence (eight stages) were characterized by 2D NMR. Additionally, a comparison between this low redox potential laccase-mediator and a high redox potential laccase-mediator treatment using $P$. cinnabarinus laccase and HBT on delignification and saccharification yield was also performed. Finally, the relationships between lignin content and structure in the pretreated raw material and efficiency of the carbohydrate enzymatic saccharification have been targeted.

Eucalypt Lignin Modification by a Commercial Laccase and a Natural Mediator

The detailed study of lignin structure along the enzymatic sequence revealed that some of the main changes observed by 2D NMR of the whole material after the complete sequence, namely the absence of $\mathrm{G}$ units and resinol substructures together with a high decrease in $\beta-O-4$ ' alkyl-aryl ethers, were already evidenced after two cycles of laccase-mediator treatment and alkaline extraction (stage 5). However, the most remarkable decreases in these units and substructures were observed indeed in the second enzymatic treatment (stage 3) together with the most remarkable increase in $\mathrm{C}_{\alpha}$-oxidized lignin units $\left(\mathrm{S}^{\prime}\right)$. This modification of lignin structure was produced in the enzymatic stages. Even more, although the first cycle of pretreatment did not produce any decrease of the lignin content (as revealed by Klason lignin determination) the 2D NMR results revealed modification of the lignin structure, already in the first enzymatic treatment (stage 1) including decrease in $\beta-O-4^{\prime}$ alkyl-aryl ethers, resinol substructures, and increase in the $\mathrm{S} / \mathrm{G}$ ratio. This indicates that the laccasemediator treatment is able to modify lignin in a lignocellulosic material without a previous chemical pretreatment. The most remarkable effect observed during the alkaline peroxide stages was the decrease of $\mathrm{C}_{\alpha}$-oxidized lignin units $\left(\mathrm{S}^{\prime}\right)$ as well as acetylated xylan units $\left(\mathrm{X}^{\prime}\right)$. The positive effect of the alkaline peroxide extraction following the enzymatic treatment with M. thermophila laccase and $\mathrm{MeS}$ was also observed during the delignification of eucalypt paper pulp [20]. The pretreatment with $M$. thermophila laccase alone, also produced a decrease in $\beta-O-4^{\prime}$ alkyl-aryl ethers and increase in $\mathrm{C}_{\alpha}$-oxidized lignin units although to a less extent that in the laccase-mediator treatment. Likewise, removal of resinol substructures also occurred although in the last enzymatic treatment. The amount of $\mathrm{G}$ units decreased along the sequence but they were still present at the end of the pretreatment. The modification of lignin structure by the laccase alone, without mediator, suggests either the modification of the phenolic-type lignin (maybe enabling a progressive degradation of the polymer) [30] or the involvement of natural phenolic structures mediating the enzymatic oxidation.
The 2D NMR analysis of CEL preparations corroborated the main findings observed in the pretreated whole feedstock compared with the controls, namely the increase in the $\mathrm{S} / \mathrm{G}$ ratio and $\mathrm{C}_{\alpha}$-oxidized lignin units along the sequence, and the decrease in resinol substructures, especially evident in the treatment with laccase and mediator. On the other hand, when comparing the lignin composition of the filtrates obtained at different stages of the pretreatment with the CEL it can be observed that in control samples, a similar relative composition of aromatic units and inter-unit linkages was observed in both lignins from stage 2 revealing that alkaline extraction in this stage extracted part of the lignin present in wood samples without altering its composition. However, in stage 8 , the lignin present in the filtrates lacked phenylcoumarans, resinols, and spirodienones substructures whereas these substructures were present in the corresponding CEL preparations. Concerning lignins from laccase (alone) and laccase-mediator pretreatment, a relatively similar composition was also observed between lignins in filtrate and wood (CEL) from stage 2 , including the proportion of lignin inter-unit linkages (per 100 phenylpropane units). However, a significant decrease in the number of side-chains involved in the different lignin substructures was observed in the filtrates of stage 8 compared with its corresponding CEL lignin indicating that lignin in the filtrate was more depolymerized than residual lignin in wood. In addition, a stronger increase in $\mathrm{C}_{\alpha}$-oxidized $\mathrm{S}$ units $\left(\mathrm{S}^{\prime}\right)$ from stage 2 to 8 in lignin from filtrates than in CEL lignin was observed. In CEL preparation the increase in $\mathrm{S}^{\prime}$ was associated with an increase in $\beta-O-4^{\prime}$ ether linked $\mathrm{C}_{\alpha}$-oxidized side chains $\left(\mathrm{A}_{\mathrm{ox} \beta}\right)$ whereas the contrary happened in lignin from filtrates. This suggests that these oxidized units in CEL lignin are linked while in filtrates may be not. On the other hand, the increase in $\mathrm{S} / \mathrm{G}$ ratio observed along the sequence in both the whole samples and isolated lignin (CEL) was not paralleled by a predominance of $\mathrm{G}$ units in the filtrates. This may suggest that $\mathrm{G}$ units degraded by enzymatic treatment undergo either condensation reactions forming $5-5^{\prime}$ or $4-O-5^{\prime}$ linkages, or reactions leading to aromatic ring opening.

\section{Comparison of Lignin Modification \\ by $M$. thermophila/P. cinnabarinus Treatments}

For comparative purposes, the pretreatment of eucalypt wood was also carried out with the high redox potential laccase from the basidiomycete $P$. cinnabarinus and the mediator HBT, and the results compared with those obtained in the pretreatment with the low redox potential laccase from the ascomycete M. thermophila and the phenolic mediator MeS. Although the decrease in lignin content after the whole sequence of the pretreatment of eucalypt wood with both laccase-mediator systems was similar $(\sim 50 \%)$, the structure of the residual lignin in eucalypt feedstock after both treatments showed some differences. Although in both cases, the lignin 
composition in terms of aromatic units was the same since both lignins lacked $\mathrm{G}$ units after the treatments, the residual lignin of the P. cinnabarinus laccase and HBT treatment was more oxidized (higher amount of $\mathrm{C}_{\alpha}$-oxidized lignin units) and degraded (lower amount of $\beta-O-4^{\prime}$ alkyl-aryl ethers per 100 phenylpropane units) than lignin in the treatment with $M$. thermophila laccase-MeS. The differences in residual lignin structure (and content) with both treatments became more evident in the initial stages (cycle 1) of the treatment. At stage 2 , the lignin from treatment with P. cinnabarinus laccase and HBT was only constituted by $\mathrm{S}$ units (some of them oxidized) and rather degraded whereas the lignin from the pretreatment with $M$. thermophila laccase-MeS was constituted by both $\mathrm{S}$ and $\mathrm{G}$ units ( $\mathrm{S} / \mathrm{G}$ ratio of 5.4), was less degraded (higher amount of $\beta-O-4^{\prime}$ alkyl-aryl ethers) and still contained high content of resinol substructures. Likewise, an initial decrease $(14 \%)$ in lignin content was observed only in the treatment with $P$. cinnabarinus laccase. In a similar way, higher delignification of eucalypt pulp was attained in the treatment with $P$. cinnabarinus laccase and HBT compared with that using $M$. thermophila laccase and MeS [31]. Nevertheless, although at a different rate, wood lignin modification by laccase in the presence of MeS also yielded a structural modification pattern characterized by extensive $\mathrm{C}_{\alpha}$-oxidation (as shown by 2D NMR) suggesting that the attack mechanism by laccase in the presence of MeS is the same reported by laccase-HBT. This agrees with results from model compounds showing that laccase in the presence of phenolic mediators oxidize nonphenolic aromatic compounds via a hydrogen abstraction mechanism [32].

The pretreatments of eucalypt feedstock with the two laccases in the absence of mediators already showed differences in lignin modification. At initial stages (step 2), no decrease in lignin content was observed with either M. thermophila or P. cinnabarinus laccases alone. However, whereas the lignin structure of wood from treatment with the former laccase was barely modified (with respect to the control), that from treatment with the latter laccase showed an increase in the $\mathrm{S} / \mathrm{G}$ ratio compared with the control (from 2.4 to 6.2), an increase in $\mathrm{C}_{\alpha}$-oxidized lignin units and a decrease in the amount of $\beta-O-4^{\prime}$ alkyl-aryl ethers (per 100 phenylpropane units). Surprisingly, at the end of the sequence (stage 8), only M. thermophila laccase, and not that from P. cinnabarinus, decreased the eucalypt lignin content (about $20 \%$ ) when applied alone, in spite of the latter being a highredox potential laccase unlike the former. A similar finding was reported in the treatment of eucalypt pulp with these two laccases [20]. In spite of this, the structure of residual lignin from the treatment with $P$. cinnabarinus laccase was modified in a higher extent than that from $M$. thermophila laccase, being more oxidized and depolymerized and presenting a higher $\mathrm{S} / \mathrm{G}$ ratio. A similar pattern of degradation, although with differences in reaction rates, has been reported in the reaction of lignin model compounds with two laccases differing in their redox potential [33].

Lignin Modification by Laccase-Mediator and Enzymatic Saccharification Yields

In addition of studying the modification of lignin structure along the enzymatic pretreatment sequence with the two laccase-mediator systems, another goal of the present work was to study the relationships between lignin content and structure in the pretreated raw material and the efficiency of the enzymatic saccharification. First, it should be mentioned that some increase in sugar release (up to 10 and $15 \%$ ) were observed in control samples after four cycles of pretreatment (not observed after one cycle) of both treatments with respect to initial wood. This could be related with the removal of acetylated xylan units $\left(\mathrm{X}^{\prime}\right)$ produced by the alkaline extraction conditions. These units were still present in control samples after one cycle of pretreatment but not after four cycles. The effect of alkaline saponification of acetyl ester bonds in the improvement of enzymatic accessibility to the polysaccharides has been reported [34].

The delignification $(\sim 50 \%)$ produced at the end of the pretreatment by the two laccase-mediator systems correlated in both cases with similar $(\sim 30 \%)$ increases in glucose yield. Likewise, at the beginning of the sequence (stage 2), the pretreatment with $M$. thermophila-MeS did not decrease the eucalypt lignin content and consequently no increase in glucose release was observed, whereas an increase in glucose release (by $8 \%$ ) was produced in the pretreatment with P. cinnabarinus-HBT where a decreased the lignin content (14\%) was attained. This suggests a direct correlation between the decrease in lignin content and increase in enzymatic saccharification yield with the laccase-mediator treatments. This correlation is also observed in the pretreatments with laccases alone at the beginning of the sequence where no decrease in lignin content and no increase in enzymatic saccharification were produced. Different findings have been reported on the effects of wood lignin content on sugar release $[2,35]$.

In addition to lignin content, lignin composition ( $\mathrm{S} / \mathrm{G}$ ratio) and structure can also influence enzymatic saccharification. As described above, the removal of guaiacyl lignin units was one of the main features observed during the pretreatment of eucalypt feedstock with the two different laccase-mediator systems. The presence of less guaiacyl units results in a less branched lignin structure, which may facilitate carbohydrates accessibility and hydrolysis [36]. This can explain why at the end of the sequence of the pretreatment with P. cinnabarinus laccase alone (stage 8) a slight increase in glucose release (about $4 \%$ ) was produced without a decrease in lignin content. This increase in glucose release can be attributed to the modification of lignin structure, namely the strong increase in 
$\mathrm{S} / \mathrm{G}$ ratio (from 3.8 to 17.5 ) besides a higher lignin degradation by $P$. cinnabarinus laccase pretreatment. However, the increase of $\mathrm{S} / \mathrm{G}$ ratio (from 2.9 to 5.4) after one cycle of M. thermophila-MeS pretreatment did not increase the sugar release. This suggests that $\mathrm{S} / \mathrm{G}$ ratio alone did not correlate with the amount of sugar released. Although it is generally understood that low lignin contents increase the ability of cellulolytic enzymes to hydrolyze plant fibers [35, 37], no clear trend has been found on the effect of $\mathrm{S} / \mathrm{G}$ ratio on sugar release [2, 29, 37]. It can be concluded that lignin content combined with lignin structure determines the efficiency of enzymatic hydrolysis. As lignin content decrease, the released sugars increase. If lignin content is the same (and not very high), a higher $S / G$ ratio (by removal of guaiacyl units) promote a more accessible substrate and results in higher enzymatic hydrolysis efficiency.

\section{Conclusions}

This work shows further insights into the modification of lignin structure and content produced by two laccase-mediator pretreatments consisting of a sequence of successive laccasemediator and alkaline extraction stages, directly on ground lignocellulosic material (i.e., without a previous chemical deconstruction) and its relationship with enzymatic saccharification yields. Both high and low redox potential laccase-mediator pretreatments delignified eucalypt wood (up to $50 \%$ ) and improved ( $\sim 30 \%)$ enzymatic sugar release after the complete multistage sequence, although differences on lignin modification/removal extents were observed at the several stages of the sequence. The HSQC NMR spectra of the lignocellulosic samples showed a significant decrease of both aromatic (with preference of $\mathrm{G}$ units) and aliphatic lignin signals after the enzymatic treatments, and provided strong evidence for a $\mathrm{C}_{\alpha}$-oxidation degradation mechanism, with high presence of oxidized $\mathrm{S}$ units in the residual lignin. The results obtained demonstrate that the reduction in lignin content effectively overcame cell wall recalcitrance to enzymatic saccharification. However, lignin composition ( $\mathrm{S} / \mathrm{G}$ ratio) alone may not be the main factor affecting enzymatic hydrolysis, and changes in lignin structure most probably also cause a significant effect.

Acknowledgments This study was funded by the INDOX (KBBE2013-7-613549) EU-project and the LIGNOCELL (AGL2011-25379) and HIPOP (BIO2011-2669) Spanish MICINN projects (co-financed by FEDER funds). J. Rencoret acknowledges the CSIC JAE-Doc contract of the program "Junta para la Ampliación de Estudios" co-financed by the European Social Fund (ESF). H. Lund and L. Kalum from Novozymes (Bagsvaerd, Denmark) are acknowledged for the cellulases (Celluclast and Novozym 188) and the M. thermophila laccase, Beldem (Andenne, Belgium) for the P. cinnabarinus laccase and J. Romero (ENCE, Spain) for the eucalypt wood samples. Manuel Angulo (CITIUS, University of Seville) is acknowledged for providing technical assistance in the NMR analyses.

\section{References}

1. Papa G, Varanasi P, Sun L, Cheng G, Stavila V, Holmes B, Simmons BA, Adani F, Singh S (2012) Exploring the effect of different plant lignin content and composition on ionic liquid pretreatment efficiency and enzymatic saccharification of Eucalyptus globulus L. mutants. Bioresource Technol 117:352-359

2. Studer MH, DeMartini JD, Davis MF, Sykes RW, Davison B, Keller M, Tuskan GA, Wyman CE (2011) Lignin content in natural Populus variants affects sugar release. Proc Natl Acad Sci U S A 108:6300 6305

3. Li X, Ximenes E, Kim Y, Slininger M, Meilan R, Ladisch M, Chapple C (2010) Lignin monomer composition affects Arabidopsis cell-wall degradability after liquid hot water pretreatment. Biotechnol Biofuels 3

4. Martín-Sampedro R, Rahikainen JL, Johansson LS, Marjamaa K, Laine J, Kruus K, Rojas OJ (2013) Preferential adsorption and activity of monocomponent cellulases on lignocellulose thin films with varying lignin content. Biomacromolecules 14:1231-1239

5. Pareek N, Gillgren T, Jönsson LJ (2013) Adsorption of proteins involved in hydrolysis of lignocellulose on lignins and hemicelluloses. Bioresource Technol 148:70-77

6. Rahikainen JL, Martin-Sampedro R, Heikkinen H, Rovio S, Marjamaa K, Tamminen T, Rojas OJ, Kruus K (2013) Inhibitory effect of lignin during cellulose bioconversion: the effect of lignin chemistry on non-productive enzyme adsorption. Bioresource Technol 133:270-278

7. Nakagame S, Chandra RP, Saddler JN (2010) The effect of isolated lignins, obtained from a range of pretreated lignocellulosic substrates, on enzymatic hydrolysis. Biotechnol Bioeng 105:871-879

8. Martínez AT, Ruiz-Dueñas FJ, Martínez MJ, del Río JC, Gutiérrez A (2009) Enzymatic delignification of plant cell wall: from nature to mill. Curr Opin Biotechnol 20:348-357

9. Bourbonnais R, Paice MG (1990) Oxidation of non-phenolic substrates. An expanded role for laccase in lignin biodegradation. FEBS Lett 267:99-102

10. Call H-P (1994) Verfahren zur Veränderung, Abbau oder Bleichen von Lignin, ligninhaltigen Materialien oder ähnlichen Stoffen. Patent (International) WO 94/29510

11. Poppius-Levlin K, Wang W, Tamminen T, Hortling B, Viikari L, Niku-Paavola M-L (1999) Effects of laccase/HBT treatment on pulp and lignin structures. J Pulp Paper Sci 25:90-94

12. Camarero S, García O, Vidal T, Colom J, del Río JC, Gutiérrez A, Gras JM, Monje R, Martínez MJ, Martínez AT (2004) Efficient bleaching of non-wood high-quality paper pulp using laccasemediator system. Enzyme Microb Technol 35:113-120

13. Gutiérrez A, del Río JC, Martínez AT (2009) Microbial and enzymatic control of pitch in the pulp and paper industry. Appl Microbiol Biotechnol 82:1005-1018

14. Prasetyo EN, Kudanga T, Ostergaard L, Rencoret J, Gutiérrez A, del Río JC, Santos JI, Nieto L, Jimenez-Barbero J, Martínez AT et al (2010) Polymerization of lignosulfonates by the laccase-HBT (1hydroxybenzotriazole) system improves dispersibility. Bioresource Technol 101:5054-5062

15. Widsten P, Kandelbauer A (2008) Laccase applications in the forest products industry: a review. Enzyme Microb Technol 42:293-307

16. Gutiérrez A, Rencoret J, Cadena EM, Rico A, Barth D, del Río JC, Martínez AT (2012) Demonstration of laccase-mediator removal of lignin from wood and non-wood plant feedstocks. Bioresource Technol 119:114-122

17. Palonen H, Viikari L (2004) Role of oxidative enzymatic treatments on enzymatic hydrolysis of softwood. Biotechnol Bioeng 86:550-557

18. Chen Q, Marshall MN, Geib SM, Tien M, Richard TL (2012) Effects of laccase on lignin depolymerization and enzymatic hydrolysis of ensiled corn stover. Bioresource Technol 117:186-192 
19. Rico A, Rencoret J, del Río JC, Martínez AT, Gutiérrez A (2014) Pretreatment with laccase and a phenolic mediator degrades lignin and enhances saccharification of Eucalyptus feedstock. Biotechnol Biofuels 7:6

20. Babot ED, Rico A, Rencoret J, Kalum L, Lund H, Romero J, del Río JC, Martínez AT, Gutiérrez A (2011) Towards industrially feasible delignification and pitch removal by treating paper pulp with Myceliophthora thermophila laccase and a phenolic mediator. Bioresource Technol 102:6717-6722

21. Tappi: 2006-2007 TAPPI test methods. Norcoss, GA 30092, USA: TAPPI Press

22. Selvendran RR, March JF, Ring SG (1979) Determination of aldoses and uronic-acid content of vegetable fiber. Anal Biochem 96:282292

23. Rencoret J, Marques G, Gutiérrez A, Nieto L, Santos I, JiménezBarbero J, Martínez AT, del Río JC (2009) HSQC-NMR analysis of lignin in woody (Eucalyptus globulus and Picea abies) and nonwoody (Agave sisalana) ball-milled plant materials at the gel state. Holzforschung 63:691-698

24. Kim H, Ralph J, Akiyama T (2008) Solution-state 2D NMR of ballmilled plant cell wall gels in DMSO- $\mathrm{d}_{6}$. Bioenerg Res 1:56-66

25. Rencoret J, Gutiérrez A, del Río JC (2007) Lipid and lignin composition of woods from different eucalypt species. Holzforschung 61: $165-174$

26. Rencoret J, Marques G, Gutiérrez A, Ibarra D, Li J, Gellerstedt G, Santos JI, Jiménez-Barbero J, Martínez AT, del Río JC (2008) Structural characterization of milled wood lignin from different eucalypt species. Holzforschung 62:514-526

27. Rencoret J, Gutiérrez A, Nieto L, Jiménez-Barbero J, Faulds CB, Kim H, Ralph J, Martínez AT, del Río JC (2001) Lignin composition and structure in young versus adult Eucalyptus globulus plants. Plant Physiol 155:667-682
28. Kishimoto T, Chiba W, Saito K, Fukushima K, Uraki Y, Ubukata M (2010) Influence of syringyl to guaiacyl ratio on the structure of natural and synthetic lignins. J Agric Food Chem 58:895-901

29. Santos RB, Treasure T, Gonzalez R, Phillips R, Lee JM, Jameel H, Chang HM (2012) Impact of hardwood species on production cost of second generation ethanol. Bioresource Technol 117:193-200

30. Martínez-Ínigo MJ, Kurek B (1997) Oxidative degradation of alkali wheat straw lignin by fungal lignin peroxidase, manganese peroxidase and laccase: a comparative study. Holzforschung 51: $543-548$

31. Du XY, Li J, Gellerstedt G, Rencoret J, del Río JC, Martínez AT, Gutiérrez A (2013) Understanding pulp delignification by laccasemediator systems through isolation and characterization of lignincarbohydrate complexes. Biomacromolecules 14:3073-3080

32. Calcaterra A, Galli C, Gentili P (2008) Phenolic compounds as likely natural mediators of laccase: a mechanistic assessment. J Mol Catal B-Enzym 51:118-120

33. Lahtinen M, Kruus K, Heinonen P, Sipila J (2009) On the reactions of two fungal laccases differing in their redox potential with lignin model compounds: products and their rate of formation. J Agric Food Chem 57:8357-8365

34. Zhang YHP, Lynd LR (2004) Toward an aggregated understanding of enzymatic hydrolysis of cellulose: noncomplexed cellulase systems. Biotechnol Bioeng 88:797-824

35. Yu ZY, Jameel H, Chang HM, Park S (2011) The effect of delignification of forest biomass on enzymatic hydrolysis. Bioresource Technol 102:9083-9089

36. Santos RB, Lee JM, Jameel H, Chang HM, Lucia LA (2012) Effects of hardwood structural and chemical characteristics on enzymatic hydrolysis for biofuel production. Bioresource Technol 110:232-238

37. Chen F, Dixon R (2007) Lignin modification improves fermentable sugar yields for biofuel production. Nat Biotechnol 25:759-761 